\title{
Controlled Synthesis of Polyions of Heavy Main-Group Elements in Ionic Liquids
}

\author{
Matthias F. Groh ${ }^{1}$, Alexander Wolff ${ }^{1}$, Matthias A. Grasser ${ }^{1}$ and Michael Ruck ${ }^{1,2, *}$ \\ 1 Department of Chemistry and Food Chemistry, Technische Universität Dresden, 01062 Dresden, Germany; \\ matthias.groh@chemie.tu-dresden.de (M.F.G.); alexander.wolff@chemie.tu-dresden.de (A.W.); \\ matthias.grasser@chemie.tu-dresden.de (M.A.G.) \\ 2 Max Planck Institute for Chemical Physics of Solids, Nöthnitzer Strasse 40, 01187 Dresden, Germany \\ * Correspondence: michael.ruck@tu-dresden.de; Tel.: +49-351-4633 (ext. 4769)
}

Academic Editors: Andreas Taubert and Peter Hesemann

Received: 5 July 2016; Accepted: 23 August 2016; Published: 1 September 2016

\begin{abstract}
Ionic liquids (ILs) have been proven to be valuable reaction media for the synthesis of inorganic materials among an abundance of other applications in different fields of chemistry. Up to now, the syntheses have remained mostly "black boxes"; and researchers have to resort to trial-and-error in order to establish a new synthetic route to a specific compound. This review comprises decisive reaction parameters and techniques for the directed synthesis of polyions of heavy main-group elements (fourth period and beyond) in ILs. Several families of compounds are presented ranging from polyhalides over carbonyl complexes and selenidostannates to homo and heteropolycations.
\end{abstract}

Keywords: amines; ionic liquids; ionothermal; main-group elements; modifications; polyanions; polycations; starting materials; synthesis parameters; vapor pressure

\section{Introduction}

Ionic liquids (ILs) — Often defined as salts with melting points below $100{ }^{\circ} \mathrm{C}$-have actually been known for quite a long time. In the decades after the description of the first representative ethylammonium nitrate by Paul Walden in 1914 [1], this valuable family of compounds fell into oblivion. Despite pioneering works [2], there had only been approximately 20 articles per year on ILs until 1995 [3]. Beginning with the late 1990s, the annual number of publications rose tremendously to about 9200 in the year 2015, according to "Web of Science", indicating the huge interest of different research communities.

Usually, ILs are constituted from bulky organic cations and (often) polyatomic anions, which can be selected in order to tune the properties of the IL. Typical cations range from simple quaternary ammonium or phosphonium ions over substituted imidazolium or pyridinium rings to more complex cations, such as the so-called TAAILs (Tunable Aryl Alkyl Ionic Liquids) [4]. A similar variety can be found among the anions including, for example, simple halides, complex organic anions, or halogenidometalates [5]. Among others, the latter can be utilized to introduce additional physical properties like magnetic moments [6].

Owing to the distinctive physicochemical properties of ILs (wide liquidus range, high redox and thermal stability, negligible vapor pressure, and tunable polarity) and their advantages over organic solvents, classic melts, or solid state reactions, their applications include separation techniques [7-9], lubrication [10], electrodeposition [11], acting as electrolytes in photovoltaic devices (e.g., solar cells) [12-14], catalysis for clean technology [15-18], polymerization processes [19], crystal engineering of a wide range of inorganic substances [20-25], and syntheses of new inorganic materials in general [23,26-51]. Recently, several comprehensive reviews on syntheses of inorganic compounds 
in ILs have been published by Taubert [52], Feldmann [28], Dehnen [51], Janiak [42,53], Scrosati and Passerini [48], Morris [54], Mudring [55], Prechtl [56], Zhu [57], Dai [58], and Ruck [23,27,59] among others.

Despite the abundance of inorganic compounds yielded by IL approaches, the syntheses remain a "black box" in several cases. Not only are the mechanisms of product formation barely examined but the overall role of the IL might also be vague. The latter can range from being a mere lubricant for solid state reactions via acting as solvent for (a part of) the starting materials to crucial directive properties leading to tunable products. In addition, the interplay of ILs with additives or directing agents has to be investigated further. Therefore, either in situ reaction monitoring [60-62] or comparisons of several syntheses can elucidate the influence of ILs. The present review article aims to highlight a variety of reaction parameters and techniques for the directed synthesis of polyions of heavy main-group elements (fourth period and beyond) in ILs (cation and anion abbreviations in Table 1) in order to provide researchers with an insight into promising synthetic approaches. We will summarize or deduce crucial reaction parameters and techniques and-in several cases-demonstrate the benefit of utilizing an IL in comparison to classic synthetic routes. The review is subdivided into sections on polyanions and polycations, and further into subsections about specific subgroups with their decisive reaction parameters.

Table 1. Synopsis of used abbreviations of cations and anions of ILs in the review.

\begin{tabular}{|c|c|}
\hline Abbreviation & Full Name \\
\hline [EHIm] & 1-ethylimidazolium \\
\hline [EMIm] & 1-ethyl-3-methylimidazolium \\
\hline [PMIm] & 1-propyl-3-methylimidazolium \\
\hline [BMIm] & 1-butyl-3-methylimidazolium \\
\hline [HMIm] & 1-hexyl-3-methylimidazolium \\
\hline [DMIm] & 1-dodecyl-3-methylimidazolium \\
\hline [BMMIm] & 1-butyl-2,3-dimethylimidazolium \\
\hline [PMMIm] & 1-propyl-2,3-dimethylimidazolium \\
\hline$\left[\mathrm{C}_{4} \mathrm{MPyr}\right]$ & butyl-methylpyrrolidinium \\
\hline$\left[\mathrm{C}_{10} \mathrm{MPyr}\right]$ & decyl-methylpyrrolidinium \\
\hline$\left[\mathrm{N}(\mathrm{n}-\mathrm{Bu})_{3} \mathrm{Me}\right]$ & tributylmethylammonium \\
\hline$\left[\mathrm{P}_{4444}\right]$ & tetrabutylphosphonium \\
\hline$\left[\mathrm{P}_{66614}\right]$ & trihexyl-tetradecylphosphonium \\
\hline$\left[\mathrm{P}(\mathrm{Bz})(\mathrm{Ph})_{3}\right]$ & benzyl(triphenyl)phosphonium \\
\hline$\left[\mathrm{CTf}_{3}\right]$ & tristriflylmethanide, tris(trifluoromethanesulfonyl)methanimide \\
\hline$\left[\mathrm{NTf}_{2}\right]$ & triflimide, bis(trifluoromethanesulfonyl)imide \\
\hline [OTf] & triflate, trifluoromethanesulfonate \\
\hline
\end{tabular}

\section{Polyanions}

Several polyanions, among them also polyoxometalates [63], have been synthesized in ILs. Herein, we focus on heavy polyhalides, carbonyl clusters, and selenidostannates. Owing to the abundance of synthesized compounds, crucial reaction parameters as well as the influence or benefit, respectively, of the ILs can be deduced.

\subsection{Starting Materials with High Vapor Pressure}

The ability of ILs to decrease the vapor pressure of delicate volatile compounds and, simultaneously, to provide access to dissolved species has been utilized for the synthesis of several heavy main-group element polyanions. In order to demonstrate the potential of this method, we discuss the utilization of halogens and metal carbonyls in IL-based syntheses.

The interplay between ILs and gases has been studied intensively for many years. Some gases, for example $\mathrm{CO}_{2}$ and $\mathrm{SO}_{2}$, proved to feature a remarkable solubility in some ILs [16,64-66]. The interplay between gaseous species and ILs can be manifold [64]. For $\mathrm{CO}_{2}$, interactions with 
the anions of ILs have been observed [67], and the gases $\mathrm{PH}_{3}$ and $\mathrm{BF}_{3}$ are dissolved via chemical complexation [68].

\subsubsection{Polyhalides}

Intriguing examples for the utilization of halogens are the polybromides synthesized in ILs [43,69-72]. While polyiodides were known with up to 29 iodine atoms [73], the size of the corresponding polybromides was limited to a maximum of 10 atoms [74,75] before new approaches including ILs (Feldmann group) were developed [76]. This disparity is most likely due to the vapor pressure of bromine $\left(10 \mathrm{kPa}\right.$ at $2.5{ }^{\circ} \mathrm{C}$, b.p.: $\left.58.8^{\circ} \mathrm{C}\right)$ [77], which is considerably higher than for iodine $\left(10 \mathrm{kPa}\right.$ at $108{ }^{\circ} \mathrm{C}$, b.p.: $\left.184.4^{\circ} \mathrm{C}\right)$ [77]. Moreover, the reactivity of the lighter halogens necessitates a chemically stable environment, which can be provided by ILs due to their high redox stability [78]. The use of ILs lead to the isolation of several new polybromides: $\left[\mathrm{P}\left(\mathrm{Ph}_{3}\right) \mathrm{Br}\right]\left[\mathrm{Br}_{7}\right][69]\left(\left[\mathrm{P}\left(\mathrm{Ph}_{3}\right) \mathrm{Br}\right]=\right.$ triphenylphosphine bromide), $\left[\mathrm{P}(\mathrm{Bz})(\mathrm{Ph})_{3}\right]_{2}\left[\mathrm{Br}_{8}\right][69]$, [HMIm] [Brg] [70], [N(n-Bu) ${ }_{3} \mathrm{Me}_{2}\left[\mathrm{Br}_{20}\right]$ [69], [C $\mathrm{C}_{4} \mathrm{MPyr}_{2}\left[\mathrm{Br}_{20}\right]$ [43,69], and [ $\left.\mathrm{P}_{4444}\right]_{2}\left[\mathrm{Br}_{24}\right]$ (Figure 1) [71]. The anion of $\left[\mathrm{C}_{4} \mathrm{MPyr}\right]_{2}\left[\mathrm{Br}_{20}\right]$ was regarded as the bromine-richest species (aside from the element itself) at its discovery by Wolff et al. [43]. This record has been excelled by the synthesis of $\left[\mathrm{P}_{4444}\right]_{2}\left[\mathrm{Br}_{24}\right]$ and its $\left[\mathrm{Br}_{24}\right]^{2-}$ anion by Easton et al. [71].

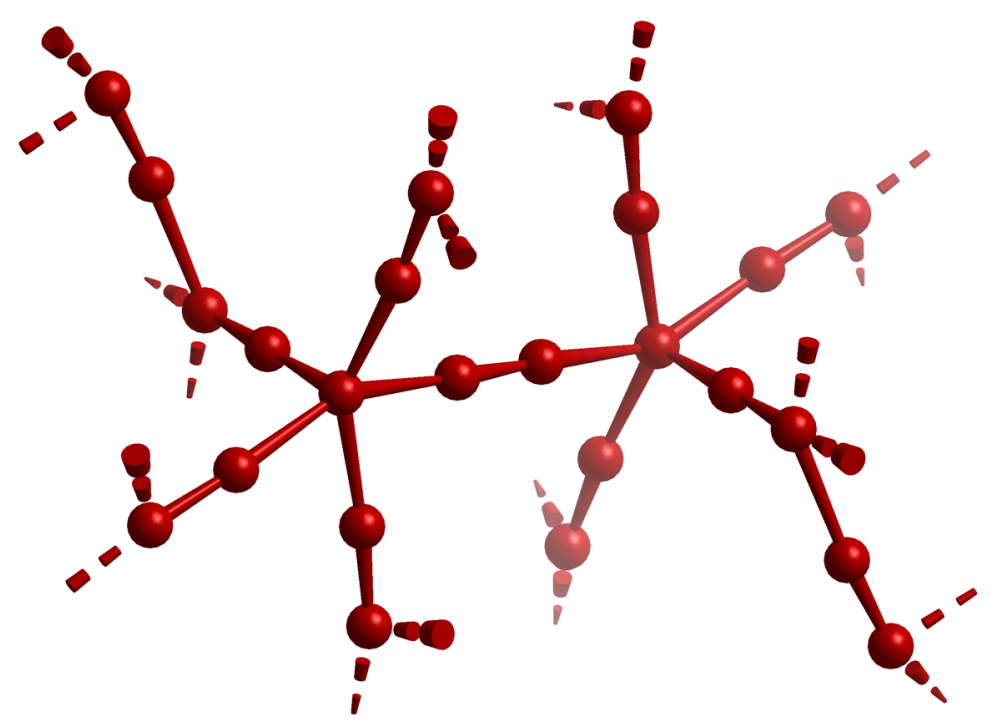

Figure 1. Visualization of the anion $\left[\mathrm{Br}_{24}\right]^{2-}$ according to [71]. $\mathrm{Br}-\mathrm{Br}$ distances with $\mathrm{d} \leq 320$ are drawn as solid lines to emphasize the $\left[\mathrm{Br}_{24}\right]^{2-}$ unit. Additional $\mathrm{Br}-\mathrm{Br}$ distances up to $370 \mathrm{pm}$ (i.e., twice the van der Waals distance [71]; dashed broken-off bonds) indicate the network character.

All IL-based syntheses of polybromides rely on one strategy: Bromide anions dissolved in an IL act as electron donors to bromine molecules. The characteristic red-brown vapor of bromine is missing above the IL at moderate temperatures [69] indicating the high solubility in and strong interactions with the IL. The same effect was also observed for iodine in the course of the synthesis of phosphorus iodides [60]. For convenient isolation of the solid product, the reaction mixture has to be liquid at room temperature or, in some cases, even below, which can be achieved by different means: either a pure room-temperature ionic liquid (RTIL), for example [HMIm][Br], is used [70] or auxiliaries, like (2-bromophenyl)diphenylphosphine, are added to the RTIL [N(n-Bu) $\left.{ }_{3} \mathrm{Me}\right]\left[\mathrm{NTf}_{2}\right]$ [69]. Another possibility is the admixture of a second IL to form eutectic mixtures, for example $\left[\mathrm{P}_{4444}\right][\mathrm{Br}] /\left[\mathrm{P}_{44414}\right]\left[\mathrm{NTf}_{2}\right][69]$ or $\left[\mathrm{C}_{10} \mathrm{MPyr}\right][\mathrm{Br}] /\left[\mathrm{C}_{4} \mathrm{MPyr}\right][\mathrm{OTf}][43,69]$.

Interestingly, only two compounds, $\left[\mathrm{P}\left(\mathrm{Ph}_{3}\right) \mathrm{Br}\right]\left[\mathrm{Br}_{7}\right]$ and $\left[\mathrm{P}(\mathrm{Bz})(\mathrm{Ph})_{3}\right]_{2}\left[\mathrm{Br}_{8}\right]$, were obtained by cooling the heated reaction mixture to room temperature [69]. To achieve crystallization of all other compounds (with larger anions), deeper cooling was necessary. In the case of $\left[\mathrm{C}_{4} \mathrm{MPyr}\right]_{2}\left[\mathrm{Br}_{20}\right]$, 
the liquid was initially cooled to $-15^{\circ} \mathrm{C}$, which lead to the crystallization of the target compound and the IL itself. By reheating to $+5{ }^{\circ} \mathrm{C}$, only crystals of the polybromide remained [43]. It seems worth noting that crystallization is only achieved if the cations are not too bulky. In the case of $\left[\mathrm{P}\left(\mathrm{Ph}_{3}\right) \mathrm{Br}\right]\left[\mathrm{Br}_{7}\right]$, adding triphenylphosphine to the eutectic mixture of $\left[\mathrm{C}_{10} \mathrm{MPyr}\right][\mathrm{Br}]$ and $\left[\mathrm{C}_{4} \mathrm{MPyr}\right][\mathrm{OTf}]$ initiated crystallization [69]. In further investigations, the structure of the IL cation was identified to be the most important parameter with respect to the bromine content of the product. Therefore, further optimizing the cation-bromine interactions might lead to polybromides with even higher bromine contents [72].

\subsubsection{Utilization of Metal Carbonyls}

Handling metal carbonyls can be cumbersome due to their high vapor pressure and toxicity. Thus, introducing a reaction medium for saver storage and handling of carbonyls would be highly beneficial. First investigations by Brown et al. on the chemistry of carbonyl compounds in ILs focused on the formation of $[\mathrm{BMIm}]\left[\mathrm{Co}(\mathrm{CO})_{4}\right]$ from the reaction of $[\mathrm{BMIm}] \mathrm{Cl}$ with $\mathrm{Na}\left[\mathrm{Co}(\mathrm{CO})_{4}\right]$ in propanone. After removing the organic solvent, the resulting blue-colored IL $[\mathrm{BMIm}]\left[\mathrm{Co}(\mathrm{CO})_{4}\right]$ did not show any mass loss, even when stored under vacuum for $48 \mathrm{~h}$, indicating the high stability of this liquid salt and its ability to provide "dissolved" carbon monoxide [79].

The first IL-based synthesis of carbonyl clusters of heavy main group elements were reported by the Feldmann group (Table 2 ). $\mathrm{Mn}_{2}(\mathrm{CO})_{10}$ or $\mathrm{Fe}(\mathrm{CO})_{5}$ were reacted with metalloid iodides in different ILs at $130^{\circ} \mathrm{C}$. Similar to the aforementioned case of polybromides, the reaction temperature is remarkably high considering the vapor pressure and boiling point of e.g., $\mathrm{Fe}(\mathrm{CO})_{5}\left(10 \mathrm{kPa}\right.$ at $44^{\circ} \mathrm{C}$, b.p.: $\left.103^{\circ} \mathrm{C}\right)[77]$.

Table 2. Synthesis of carbonyl complexes of heavy main group elements. All reactions were performed at $130^{\circ} \mathrm{C}$ in sealed ampules.

\begin{tabular}{ccccc}
\hline Carbonyl & Iodide & IL & Cluster Anion & Ref. \\
\hline $\mathrm{Mn}_{2}(\mathrm{CO})_{10}$ & $\mathrm{TeI}_{4}$ & {$[\mathrm{BMIm}][\mathrm{OTf}]$} & {$\left[\left(\mathrm{Te}_{2}\right)_{3}\left\{\mathrm{Mn}(\mathrm{CO})_{3}\right\}_{2}\left\{\mathrm{Mn}(\mathrm{CO})_{4}\right\}_{3}\right]^{-}$} & {$[80]$} \\
& $\mathrm{PbI}_{2}$ & {$[\mathrm{BMIm}]\left[\mathrm{NTf} f_{2}\right]$} & {$\left[\left(\mathrm{Pb} \mathrm{I}_{8}\right)\left\{\mathrm{Mn}(\mathrm{CO})_{5}\right\}_{6}\right]^{-2}$} & {$[81]$} \\
$\mathrm{Fe}(\mathrm{CO})_{5}$ & $\mathrm{SnI}_{4}$ & {$[\mathrm{EMIm}]\left[\mathrm{NTf}_{2}\right]$} & $\left.\left[\mathrm{FeI}(\mathrm{CO})_{3}(\mathrm{SnI})_{3}\right)_{2}\right]^{-}$ & {$[82]$} \\
& & {$[\mathrm{EHIm}]\left[\mathrm{NTf}_{2}\right]$} & {$\left[\mathrm{FeI}(\mathrm{CO})_{3}\left(\mathrm{SnI}_{3}\right)_{2}\right]^{-}$} & {$[82]$} \\
& & {$[\mathrm{PMIm}]\left[\mathrm{NTT}_{2}\right]$} & {$\left[\mathrm{FeI}(\mathrm{CO})_{3}\left(\mathrm{SnI}_{3}\right)_{2}\right]^{-}$} & {$[82]$} \\
& & {$[\mathrm{BMIm}]\left[\mathrm{NT} f_{2}\right]$} & {$\left[\left\{\mathrm{Fe}(\mathrm{CO})_{3}\right\}_{4} \mathrm{Sn}_{6} \mathrm{I}_{10}\right]^{2-}$} & {$[83]$} \\
& & {$[\mathrm{BMIm}][\mathrm{OTf}]$} & {$\left[\left\{\mathrm{Fe}(\mathrm{CO})_{3}\right\}_{4} \mathrm{Sn}_{6} \mathrm{I}_{10}\right]^{2-}$} & {$[83]$} \\
\hline
\end{tabular}

Some of the CO ligands remain bonded to the transition metal atom in the product. It is noteworthy that gaseous CO itself is just sparingly soluble in ILs [64], which matches the observation of an excess pressure of the reaction by-product $\mathrm{CO}$ while opening the sealed ampules [80]. Therefore, metal carbonyl fragments from the starting material exist under the chosen reaction conditions and are thus dissolved and available for further reactions.

The stability of the obtained compounds varies. On the one hand, [BMIm $]_{2}\left[\left(\mathrm{~Pb}_{6} \mathrm{I}_{8}\right)\left\{\mathrm{Mn}(\mathrm{CO})_{5}\right\}_{6}\right]$ (Figure 2) releases $\mathrm{CO}$ at room temperature if isolated from the IL [81]. Crystals of $[\mathrm{BMIm}]_{2}\left[\left\{\mathrm{Fe}(\mathrm{CO})_{3}\right\}_{4} \mathrm{Sn}_{6} \mathrm{I}_{10}\right]$ and $[\mathrm{BMIm}]_{6}[\mathrm{~S}]\left[\left\{\mathrm{Fe}(\mathrm{CO})_{3}\right\}_{4} \mathrm{Sn}_{6} \mathrm{I}_{10}\right]_{2}$ release $\mathrm{CO}$ upon squeezing [83]. [BMIm] $\left[\left(\mathrm{Te}_{2}\right)_{3}\left\{\mathrm{Mn}(\mathrm{CO})_{3}\right\}_{2}\left\{\mathrm{Mn}(\mathrm{CO})_{4}\right\}_{3}\right]$, on the other hand, is thermally stable up to $380{ }^{\circ} \mathrm{C}$ [80]. According to investigations by Feldmann et al., the sidechain length at the IL cation as well as the nature of the IL anions have no influence on the product formed (Table 2) [82,83].

In conclusion, the utilization of ILs allows safe handling of compounds with high vapor pressure like bromine or metal carbonyls at reaction temperatures above their boiling point due to their exceptional solubility in chosen ILs. Furthermore, dissolved species such as metal carbonyl fragments are available for reactions with, e.g., compounds of heavy main-group elements. In the case of the polybromides, the structure of the IL cation proved to be the dominant parameter for product-selective synthesis. 


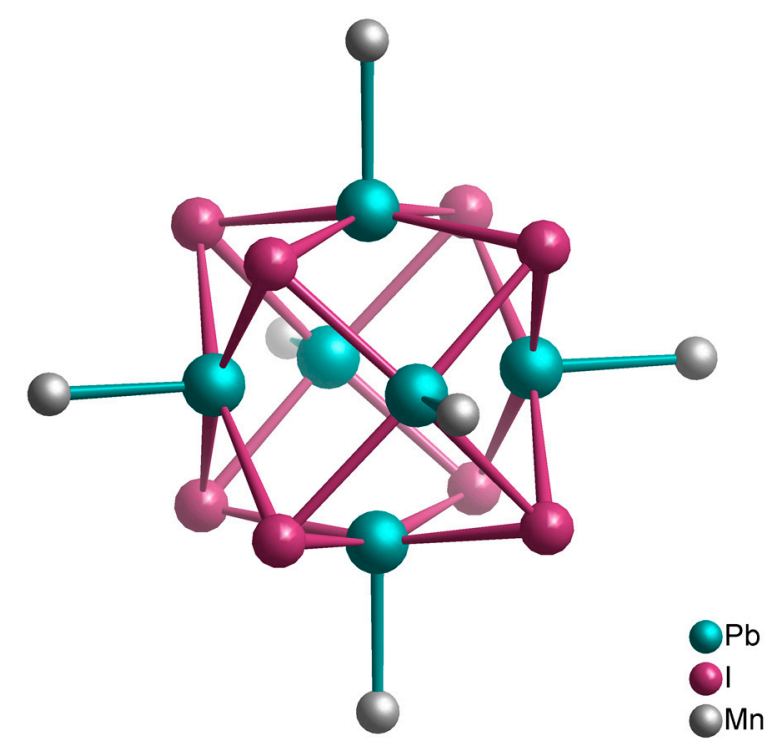

Figure 2. Visualization of the anion $\left[\left(\mathrm{Pb}_{6} \mathrm{I}_{8}\right)\left\{\mathrm{Mn}(\mathrm{CO})_{5}\right\}_{6}\right]^{2-}$ in $[\mathrm{BMIm}]_{2}\left[\left(\mathrm{~Pb}_{6} \mathrm{I}_{8}\right)\left\{\mathrm{Mn}(\mathrm{CO})_{5}\right\}_{6}\right][81]$.

The carbonyl ligands at the manganese atoms are omitted for clarity.

\subsection{Amine-Assisted Syntheses of Selenidostannates}

Structure-directing properties of ILs for the synthesis of inorganic materials are known since the initial studies of the Morris group [84-86]. They also noticed that the addition of small amounts of molecular solvents, e.g., $\mathrm{H}_{2} \mathrm{O}$, has a strong effect on the formation of the products if combined with ILs [87]. This feature was further explored during the ionothermal synthesis of molecular sieves with auxiliary amines $[61,62,88,89]$. The groups of Dehnen and Huang reported similar findings for clusters of heavy main-group elements. They noticed that the addition of amines had strong impact on the phase formation of selenidostannates synthesized from the elements or prereacted species in ILs [51,90-98]. More than 25 different selenidostannates were synthesized following this approach, which does not only illustrate the diversity of this class of compounds but also demonstrates the capability of the method. More details are given in a recent review about the synthesis and structure of selenidostannates by Dehnen et al. [51].

\subsubsection{Promoting Phase Formation}

There are many examples in which products have exclusively been obtained in the presence of an amine including the famous "zeoball"-type selenidostannates [BMMIm] ${ }_{24}\left[\mathrm{Sn}_{36} \mathrm{Ge}_{24} \mathrm{Se}_{132}\right]$ (ZBT-1) and $[\mathrm{BMIm}]_{24}\left[\mathrm{Sn}_{32.5} \mathrm{Ge}_{27.5} \mathrm{Se}_{132}\right]$ (ZBT-2), which feature the largest known discrete polyanion of main-group elements (Figure 3) [91]. Both compounds were synthesized from $\left[\mathrm{K}_{4}\left(\mathrm{H}_{2} \mathrm{O}\right)_{3}\right]\left[\mathrm{Ge}_{4} \mathrm{Se}_{10}\right]$ and $\mathrm{SnCl}_{4} \cdot 5 \mathrm{H}_{2} \mathrm{O}$ in tetrafluoridoborate ILs in the presence of DMMP (DMMP $=2,6$-dimethylmorpholine). Noteworthy, only uncharacterized Ge/Se-containing powder precipitated if the reactions were conducted in the absence of the amine, whereas an excess of it led to microcrystalline $\mathrm{SnSe}_{2}$. In another reaction, $\mathrm{SnCl}_{4} \cdot 5 \mathrm{H}_{2} \mathrm{O}$ was replaced with $\left[\mathrm{K}_{4}\left(\mathrm{H}_{2} \mathrm{O}\right)_{4}\right]\left[\mathrm{SnSe}_{4}\right]$, which contains a preformed binary unit of tin and selenium atoms. This led to the formation of ZBT-2 in the absence of DMMP. This strongly evidences that the amine is involved in the formation of initial binary (or higher) species of tin and selenium. In further experiments, $\left[\mathrm{K}_{4}\left(\mathrm{H}_{2} \mathrm{O}\right)_{3}\right]\left[\mathrm{Ge}_{4} \mathrm{Se}_{10}\right]$ and $\mathrm{SnCl}_{4} \cdot 5 \mathrm{H}_{2} \mathrm{O}$ were reacted with en (en = ethylenediamine) instead of DMMP, which led to the formation of ZBT-1 at a remarkably lower amine to IL ratio, probably due to the higher base strength of en [92]. 


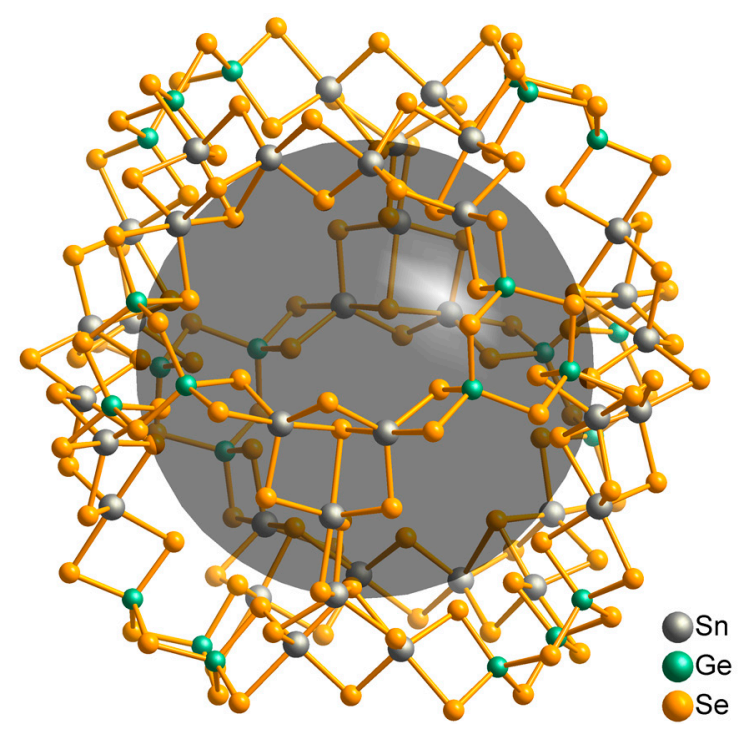

Figure 3. Visualization of the "zeoball" anion [ $\left.\mathrm{Sn}_{36} \mathrm{Ge}_{24} \mathrm{Se}_{132}\right]^{24-}$ in [BMMIm] ${ }_{24}\left[\mathrm{Sn}_{36} \mathrm{Ge}_{24} \mathrm{Se}_{132}\right]$ [91]. The disorder has been omitted for clarity. The dark sphere with a diameter of $1.54 \mathrm{~nm}$ indicates the inner void of the anion.

\subsubsection{Phase Selectivity}

Following the above-mentioned syntheses, more detailed experiments have been performed in the same system by Lin et al. aiming for a deeper understanding of the role of the amine. Different reactions in $[\mathrm{BMMIm}]\left[\mathrm{BF}_{4}\right]$ were performed under invariant conditions and only the amount of the added amine was changed (Table 3). According to these experiments, the basicity of the amine has strong influence on the phase formation [92]. With increasing basicity, the overall tendency of the $\mathrm{Ge} / \mathrm{Se}$ and $\mathrm{Sn} / \mathrm{Se}$ subunits to aggregate is decreased and the incorporation of tin into the anionic substructure is favored (Table 3). In particular, products could be precisely targeted by switching the amine from DMMP to en. Adding larger amounts of en led exclusively to the formation of a 3D network, whereas the layered (2D) and the cluster (OD) compounds are formed exclusively at lower concentrations [92].

Table 3. Influence of the amine content on the product distribution of ternary selenidostannates under otherwise identical reaction conditions. A dash indicates the absence of an identifiable product. The structural connectivity of the anionic part is indicated by 0D (cluster), 2D (layer), or 3D (framework). $\left[\mathrm{K}_{4}\left(\mathrm{H}_{2} \mathrm{O}\right)_{3}\right]\left[\mathrm{Ge}_{4} \mathrm{Se}_{10}\right](56 \mathrm{mg}), \mathrm{SnCl}_{4} \cdot 5 \mathrm{H}_{2} \mathrm{O}(40 \mathrm{mg})$, the amine, and [BMMIm] $\left[\mathrm{BF}_{4}\right](0.5 \mathrm{~g})$ were annealed at $150{ }^{\circ} \mathrm{C}$ for two days and subsequently cooled to ambient temperature [92].

\begin{tabular}{|c|c|c|}
\hline$V / \mu \mathbf{L}$ & 2,6-Dimethylmorpholine = DMMP & ethylenediamine $=$ en \\
\hline 0 & - & - \\
\hline 10 & - & $0 \mathrm{D}-[\mathrm{BMMIm}]_{24}\left[\mathrm{Sn}_{36} \mathrm{Ge}_{24} \mathrm{Se}_{132}\right]$ \\
\hline 20 & - & $0 \mathrm{D}-[\mathrm{BMMIm}]_{24}\left[\mathrm{Sn}_{36} \mathrm{Ge}_{24} \mathrm{Se}_{132}\right]$ \\
\hline 30 & $0 \mathrm{D}-[\mathrm{BMMIm}]_{24}\left[\mathrm{Sn}_{36} \mathrm{Ge}_{24} \mathrm{Se}_{132}\right]$ & $2 \mathrm{D}-[\mathrm{BMMIm}]_{2}\left[\mathrm{Ge}_{0.83} \mathrm{Sn}_{3.17} \mathrm{Se}_{9.06}\right]$ \\
\hline 50 & $0 \mathrm{D}-[\mathrm{BMMIm}]_{24}\left[\mathrm{Sn}_{36} \mathrm{Ge}_{24} \mathrm{Se}_{132}\right]$ & $2 \mathrm{D}-[\mathrm{BMMIm}]_{2}\left[\mathrm{Ge}_{0.83} \mathrm{Sn}_{3.17} \mathrm{Se}_{9.06}\right]$ \\
\hline 100 & $\begin{array}{c}\text { OD-[BMMIm }]_{24}\left[\mathrm{Sn}_{36} \mathrm{Ge}_{24} \mathrm{Se}_{132}\right] \\
2 \mathrm{D}-[\mathrm{BMMIm}]_{2}\left[\mathrm{Ge}_{0.83} \mathrm{Sn}_{3.17} \mathrm{Se}_{9.06}\right]\end{array}$ & $3 \mathrm{D}-[\mathrm{BMMIm}]_{8}\left[\mathrm{Sn}_{18} \mathrm{Se}_{40}\right]$ \\
\hline$>200$ & microcrystalline $\mathrm{SnSe}_{2}$ & - \\
\hline
\end{tabular}

In the case of the synthesis of binary selenidostannates from elemental Sn and Se by Li et al. (Table 4), 3D-[PMMIm] $]_{4}\left[\mathrm{Sn}_{9} \mathrm{Se}_{20.93}\right]$ was formed consisting of [ $\left.\mathrm{SnSe}_{4}\right]$ and $\left[\mathrm{SnSe}_{3}\left(\mathrm{Se}_{2}\right)_{0.9} \mathrm{Se}_{0.1}\right]$ tetrahedra, which are connecting $\left[\mathrm{Se}_{3} \mathrm{Se}_{4}\right]$ semicubes. In contrast to the work of the Dehnen group, increasing the amount of amine led to the formation of $2 \mathrm{D}-[\mathrm{PMMIm}]_{2}\left[\mathrm{Sn}_{3} \mathrm{Se}_{7}\right][90,94]$. It becomes 
evident that tuning only the amount of amine does not necessarily determine the dimensionality of the crystallized anion. Increased addition of amines led to two-dimensional anions in the case of binary anions and to 3D-networks for ternary ones (Table 3). This is most likely because other factors, e.g., temperature or the shape of the cation, also play an important role $[90,93,94]$. Therefore, if an undesired dimensionality results from a synthesis with auxiliary amines, increasing as well as decreasing of the amine content should be considered.

Table 4. Impact of the amine content on the product distribution of binary selenidostannates under otherwise identical reaction conditions. Sn (1 mmol), Se (2.5 mmol), hydrazine hydrate, and [PMMIm]Cl ( $1 \mathrm{~g}$ ) were annealed at $160{ }^{\circ} \mathrm{C}$ for 5 days and subsequently cooled to ambient temperature [90].

\begin{tabular}{cc}
\hline $\boldsymbol{n}(\mathrm{IL}): \boldsymbol{n}$ (hydrazine hydrate) & Product \\
\hline (without amine) & 3D-[PMMIm $]_{4}\left[\mathrm{Sn}_{9} \mathrm{Se}_{20.93}\right]-$-nanoparticles $_{2}$ \\
$4.9: 1.0$ & 3D-[PMMIm $]_{4}\left[\mathrm{Sn}_{9} \mathrm{Se}_{20.93}\right]$ \\
$4.9: 1.6$ & $2 \mathrm{D}-[\mathrm{PMMIm}]_{8}\left[\mathrm{Sn}_{17} \mathrm{Se}_{38}\right]$ \\
$2.0: 15.0$ & $2 \mathrm{D}-[\mathrm{PMMIm}]_{8}\left[\mathrm{Sn}_{17} \mathrm{Se}_{38}\right]$ \\
& $2 \mathrm{D}-[\mathrm{PMMIm}]_{2}\left[\mathrm{Sn}_{3} \mathrm{Se}_{7}\right]$ \\
\hline
\end{tabular}

\subsubsection{Crystal Growth}

As mentioned above, it was possible to synthesize the "zeoball" compound ZBT-2 without addition of amines. However, it was noted that crystal quality and yield were poor compared to the amine-assisted synthesis [91]. Therefore, the amines apparently play a role during crystal growth.

This phenomenon has also been observed in NMR experiments during the synthesis of molecular sieves [61]. In their experiments, $\mathrm{Xu}$ et al. found that imidazolium cations form hydrogen bonds with the amine molecules during crystallization. These intermediates were identified as structure directing agents for the forming solid. The imidazolium cations themselves are pore-filling agents during crystal growth $[61,62]$. The influence of hydrogen bonding in the course of crystallization was also observed for the transformation of 2D-[BMMIm] ${ }_{16}\left[\mathrm{Sn}_{24} \mathrm{Se}_{56}\right]$ into 1D-[BMMIm] $]_{4}\left[\mathrm{Sn}_{6} \mathrm{Se}_{14}\right]$ or $1 \mathrm{D}-[\mathrm{BMMIm}]_{3}[\mathrm{DMMPH}]\left[\mathrm{Sn}_{6} \mathrm{Se}_{14}\right]$. Heating $2 \mathrm{D}-[\mathrm{BMMIm}]_{16}\left[\mathrm{Sn}_{24} \mathrm{Se}_{56}\right]$ to $150{ }^{\circ} \mathrm{C}$ led to the partial transformation into 1D-[BMMIm] $]_{4}\left[\mathrm{Sn}_{6} \mathrm{Se}_{14}\right]$, whereas 1D-[BMMIm] $]_{3}[\mathrm{DMMPH}]\left[\mathrm{Sn}_{6} \mathrm{Se}_{14}\right]$ was obtained under the same conditions by adding DMMP. Interestingly, the yield of $1 \mathrm{D}-[\mathrm{BMMIm}]_{4}\left[\mathrm{Sn}_{6} \mathrm{Se}_{14}\right]$ is low even after long reaction times. The transformation into $1 \mathrm{D}-[\mathrm{BMMIm}]_{3}[\mathrm{DMMPH}]\left[\mathrm{Sn}_{6} \mathrm{Se}_{14}\right]$, however, is almost quantitative after two days. Lin et al. supposed that the protonation of DMMP and the resulting DMMPH cation is advantageous for the formation of the 1D structure, which is otherwise seemingly disfavored. Additionally, the transformation can be reversed by reacting any of the 1D-compounds with en. It was pointed out that in this case, en might play an important role as auxiliary agent that forms intermediate selenium-hydrogen bonds [93]. Indeed, hydrogen bridges between en and selenium were later recognized in selenenidostannates with metal-amine complexes (MACs) acting as cations [95-98]. For example, in (BMMIm) $)_{3}\left[\mathrm{Ni}(\mathrm{en})_{3}\right]_{2}\left[\mathrm{Sn}_{9} \mathrm{Se}_{21}\right] \mathrm{Cl}$, hydrogen bonds have been found between en and the selenium atoms of the ${ }_{\infty}^{2}\left[\mathrm{Sn}_{3} \mathrm{Se}_{7}\right]^{2-}$ layers. However, this compound also demonstrates the complexity and diversity of different interactions between the MAC, the imidazolium cation, the chloride anion, and the selenium atoms of the selenidostannate layer (Figure 4) [98].

In conclusion, the combination of amines and ILs enabled the synthesis of a variety of selenidostannates. The introduction of auxiliary amines provides several additional reaction parameters. The amount, structure, and basicity of the amine can influence the dimensionality of the polyanions as well as their crystallization. The reaction mechanism includes formation of hydrogen bonds between the amines and dissolved starting materials as well as the cations of the ILs. Thus, utilization of amines or comparable auxiliaries could be beneficial for many other syntheses. 


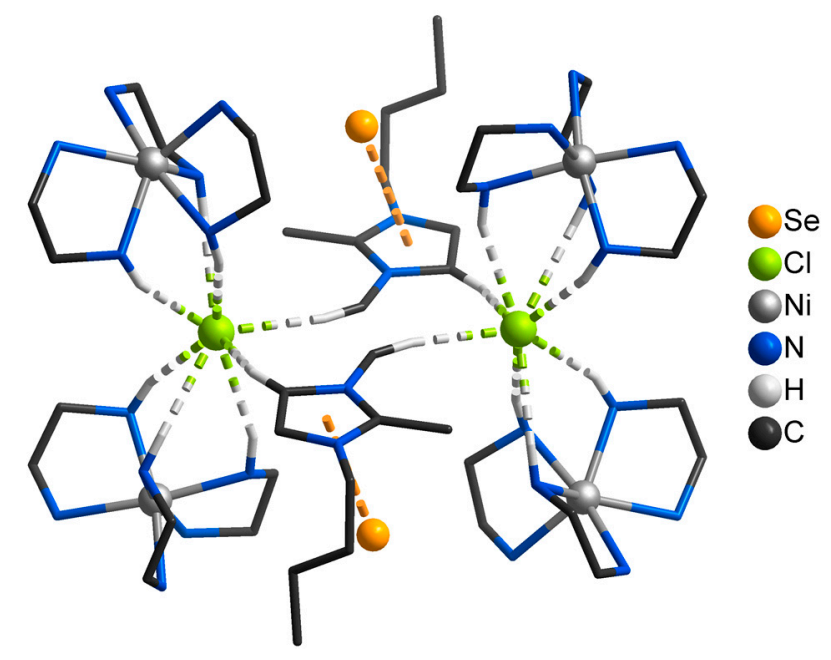

Figure 4. Visualization of the metal-amine complexes (MAC) in [BMMIm $]_{3}\left[\mathrm{Ni}(\mathrm{en})_{3}\right]_{2}\left[\mathrm{Sn}_{9} \mathrm{Se}_{21}\right] \mathrm{Cl}[98]$. The disorder and the anion except for one selenium atom each is omitted for clarity. Hydrogen bonds are pictured as green-grey dashed lines and anticipated anion- $\pi$ interactions as orange dashed lines. Hydrogen atoms are only depicted if participating in bonds toward chlorine atoms. The figure was developed according to [98].

\section{Polycations}

\subsection{Homopolycations-Adjustments via Redox Potential and Starting Materials}

While polyanions are generally synthesized in (Lewis-)basic media, polycations of heavy main group elements are usually obtained from (Lewis-)acidic solutions such as oleum or more generally in systems with only weakly coordinating anions or solvent molecules such as $\mathrm{Na}\left[\mathrm{AlCl}_{4}\right]$ melts or liquid $\mathrm{SO}_{2}$. Weakly coordinating anions (e.g., weak Lewis bases) are necessary since strong Lewis bases destabilize polycations. The introduction of ILs has increased the convenience of polycation syntheses and enabled substitution of toxic substances such as benzene, $\mathrm{SO}_{2}$, or $\mathrm{AsF}_{5}$ [99]. Commonly used Lewis-acidic ILs are combinations of alkylimidazolium halides with more than equimolar amounts of aluminum or gallium trihalides $\left(M X_{3}\right)$. The excess of trihalides is beneficial for several reasons: Free $M X_{3}$ or their condensation products with $\left[M X_{4}\right]^{-}$anions such as $\left[M_{2} X_{7}\right]^{-}$act as scavengers for halide ions or other Lewis bases. This leads to increased solubility for metalloid halides (e.g., $\mathrm{Bi} X_{3}$ dissociates into $\mathrm{BiX}_{2}{ }^{+}$and $X^{-}$) and partly self-drying ILs (if the Lewis base is water) protecting the formed polycations from hydrolysis. In addition, the concentration of the different halogenidometalate species can be tuned by temperature [100], mole fraction of employed $M X_{3}$ [5], and by adding additional free $X^{-}$anions [5100]. The latter has been utilized by Ruck et al. to overcome hindered crystallization of products by adding small amounts of $\mathrm{NaCl}$ after completion of the reaction to increase the mole fraction of $\left[\mathrm{AlCl}_{4}\right]^{-}[23,26,101]$.

A variety of homoatomic polycations of group 15 or 16 elements has been synthesized in ILs $[26,27,31,99,101-104]$ and several influencing reaction parameters were deduced.

\subsubsection{Bismuth Homopolycations}

Bismuth is famous for its ability to form ligand-free homopolyanions and especially homopolycations. Three of the latter could be synthesized in Lewis-acidic ILs: $\mathrm{Bi}_{5}{ }^{3+}$ [99,104], $\mathrm{Bi}_{8}{ }^{2+}$ [26], and $\mathrm{Bi}_{9}{ }^{5+}[26,27]$. In general, IL-based syntheses of bismuth polycations are advantageous compared to classic syntheses by increasing purity and yield in addition to lowering the reaction temperature [26].

The first synthesis of $\mathrm{Bi}_{5}{ }^{3+}$ by reacting elemental bismuth with $\mathrm{BiCl}_{3}$ (molar ratio 3:1) in [BMIm] Cl-1.3 $\mathrm{AlCl}_{3}$ at room temperature was established by Ahmed et al. in 2009 [99]. As continuative experiments in our group have shown, the resulting $\mathrm{Bi}_{5}\left[\mathrm{AlCl}_{4}\right]_{3}$ is strongly favored in this system as 
long as redox reactions involving bismuth might occur and especially during reactions at elevated temperature and in highly Lewis-acidic ILs. In fact, $\mathrm{Bi}_{5}\left[\mathrm{AlCl}_{4}\right]_{3}$ can be regarded as an omnipresent (and inconvenient) side product which has to be prevented from crystallization. Reducing $\mathrm{BiCl}_{3}$ with transition metals or other moderate reducing agents typically leads to $\mathrm{Bi}_{5}\left[\mathrm{AlCl}_{4}\right]_{3}$.

In order to suppress $\mathrm{Bi}_{5}\left[\mathrm{AlCl}_{4}\right]_{3}$ and to obtain other homopolycation compounds, several strategies have proven to be viable. One possibility is the introduction of bromine, which seems to disfavor the crystallization of $\mathrm{Bi}_{5}{ }^{3+}$ : By reacting equimolar amounts of $\mathrm{Bi}$ and $\mathrm{BiBr}_{3}$ in $[\mathrm{BMIm}] \mathrm{Cl} \cdot 2 \mathrm{AlCl}_{3}$ at room temperature, pure $\mathrm{Bi}_{6} \mathrm{Br}_{7}$, which includes $\mathrm{Bi}_{9}{ }^{5+}$ polycations, is accessible. A second approach on targeting the type of crystallized polycations is by adjusting the reducing agent: The $\mathrm{Bi}_{8}{ }^{2+}$ polycation is accessible as $\mathrm{Bi}_{8}\left[\mathrm{AlCl}_{4}\right]_{2}$ by reduction of $\mathrm{BiCl}_{3}$ with elemental sodium (molar ratio 1:2.8) in $[\mathrm{BMIm}] \mathrm{Cl} \cdot 3.6 \mathrm{AlCl}_{3}$ at $140{ }^{\circ} \mathrm{C}$ with bismuth, $\mathrm{Na}\left[\mathrm{AlCl}_{4}\right]$, and $\mathrm{Bi}_{5}\left[\mathrm{AlCl}_{4}\right]_{2}$ as byproducts. Lowering the reaction temperature to $80{ }^{\circ} \mathrm{C}$ and using a less Lewis-acidic IL with 1.3 equivalents of $\mathrm{AlCl}_{3}$ leads to $\mathrm{Bi}_{8}\left[\mathrm{AlCl}_{4}\right]_{2}$ with $\mathrm{Na}\left[\mathrm{AlCl}_{4}\right]$ and bismuth as the only by products [26]. Utilizing indium, however, changes the precipitating cation to $\mathrm{Bi}_{9}{ }^{5+}$. $\mathrm{Bi}_{6} \mathrm{Cl}_{7}$ can be obtained at room temperature by the reduction of $\mathrm{BiCl}_{3}$ with indium (molar ratio 3:2) in [BMIm]Cl.2 $\mathrm{AlCl}_{3}$ [26]. The latter result might also be attributed to the oxidation of indium into (probably) $\mathrm{InCl}_{3}$, which should interact with the IL as additional Lewis acid and could tune the reaction not (only) via the redox potential.

Kloo et al. explored the formation of the $\mathrm{Bi}_{5}{ }^{3+}$ cation by reducing $\mathrm{BiCl}_{3}$ with elemental gallium in different ILs with $\mathrm{GaCl}_{3}$ as Lewis acid in different ratios [104]. Thereby, they employed [DMIm]Cl, $\left[\mathrm{C}_{4} \mathrm{MPyr}\right] \mathrm{Cl}$ as well as $\left[\mathrm{P}_{66614}\right]^{+}$in combination with $\mathrm{Cl}^{-},\left[\mathrm{BF}_{4}\right]^{-},\left[\mathrm{PF}_{6}\right]^{-}$and $\left[\mathrm{NTf}_{2}\right]^{-}$. In all cases, $\mathrm{Bi}_{5}\left[\mathrm{GaCl}_{4}\right]_{2}$ was obtained. However, they encountered difficulties to isolate single-crystalline products in all reactions [104].

\subsubsection{Tellurium Homopolycations}

Tellurium forms a large variety of polycations. Apart from $\mathrm{Te}_{4}{ }^{2+}$, which proves a dominance in Lewis-acidic $\mathrm{AlCl}_{3}$-containing ILs similar to $\mathrm{Bi}_{5}{ }^{3+}$, several other tellurium polycations (Figure 5) were accessed in ILs $[26,27,31,101-103]$. Thereby, the utilization of an IL as reaction medium can lead to extraordinary properties of the reaction product as the following example demonstrates: $\mathrm{Te}_{4}\left[\mathrm{Bi}_{0.67} \mathrm{Cl}_{4}\right]$ obtained from a gas-phase transport reaction is an conventional semiconductor. However, the closely related $\mathrm{Te}_{4}\left[\mathrm{Bi}_{0.74} \mathrm{Cl}_{4}\right]$, obtained from an IL-based low-temperature synthesis, proved to be a one-dimensional metal and type-I superconductor [31].

(a)

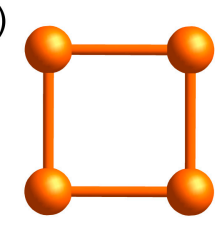

(b)

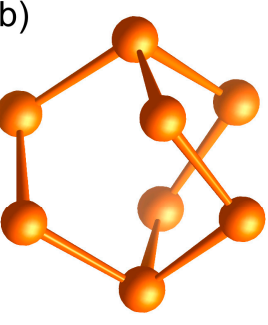

(c)

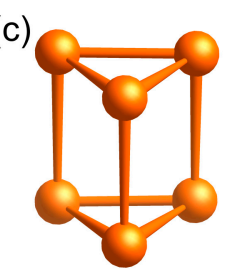

(d)

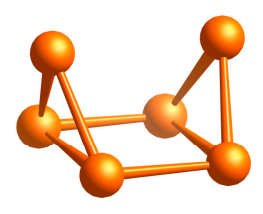

(e)

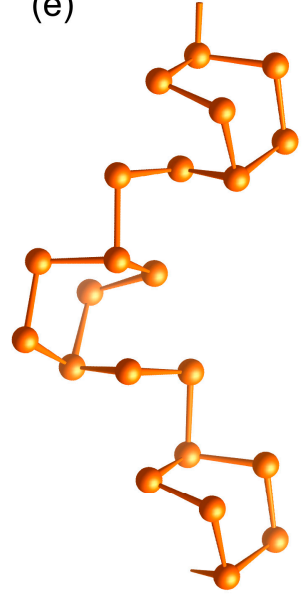

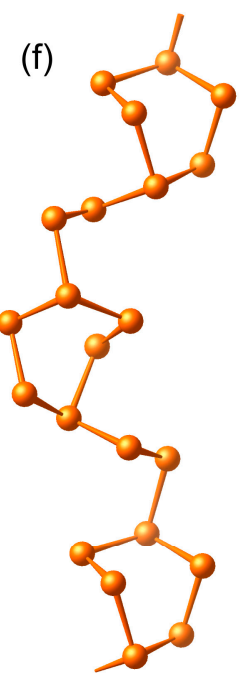

Figure 5. Synopsis of tellurium homopolycations accessible in ILs: (a) $\mathrm{Te}_{4}{ }^{2+}$ e.g., in $\mathrm{Te}_{4}\left[\mathrm{AlCl}_{4}\right]_{2}$ [101]

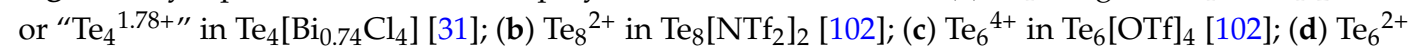
in $\mathrm{Te}_{6}\left[\mathrm{WOCl}_{4}\right]_{2}[101] ;(\mathbf{e}){ }_{\infty}^{1}\left[\mathrm{Te}_{8}\right]^{2+}$ in $\left[\mathrm{Te}_{8}\right]_{2}\left[\mathrm{Ta}_{4} \mathrm{O}_{4} \mathrm{Cl}_{16}\right][103] ;$ and (f) ${ }_{\infty}^{1}\left[\mathrm{Te}_{8}\right]^{2+}$ in $\mathrm{Te}_{8}\left[\mathrm{Bi}_{4} \mathrm{Cl}_{14}\right]$ [26]. 
In the system $\mathrm{Te}-\mathrm{Bi}-\mathrm{Cl}$, three different ternary compounds (and polycations) can be synthesized under identical conditions in the Lewis-acidic IL [BMIm] Cl. $n \mathrm{AlCl}_{3}(n=1.3-1.5)$ : the aforementioned $\mathrm{Te}_{4}\left[\mathrm{Bi}_{0.74} \mathrm{Cl}_{4}\right]$ [31] as well as the closely related semiconductors $\mathrm{Te}_{4}\left[\mathrm{Bi}_{6} \mathrm{Cl}_{20}\right]$ [26] and $\mathrm{Te}_{8}\left[\mathrm{Bi}_{4} \mathrm{Cl}_{14}\right]$ [26]. The distinctive directing parameter of these room temperature reactions has proven to be the ratio of the starting materials: If elemental tellurium, $\mathrm{TeCl}_{4}$, and $\mathrm{BiCl}_{3}$ are utilized in a proportion according to the respective composition, each compound is yielded as phase-pure product. In the case of the super-conductor $\mathrm{Te}_{4}\left[\mathrm{Bi}_{0.74} \mathrm{Cl}_{4}\right]$, the amount of $\mathrm{BiCl}_{3}$ can be increased to 3 equivalents and still the sole crystallization of the desired product does occur.

Omitting any bismuth-containing starting materials leads to the formation of pure $\mathrm{Te}_{4}\left[\mathrm{AlCl}_{4}\right]_{2}$ under the same conditions [101]. $\mathrm{Te}_{4}\left[\mathrm{Al}_{2} \mathrm{Cl}_{7}\right]_{2}$ has been synthesized during an attempt to access phosphorus-tellurium polycations by reacting equimolar amounts of tellurium, $\mathrm{Te}_{4}$, and red phosphorus in the same IL with $n=4.8$ at $80^{\circ} \mathrm{C}$ [26]. The crystallization of the identical polycation but with $\left[\mathrm{Al}_{2} \mathrm{Cl}_{7}\right]^{-}$as anion can be rationalized with the higher content of $\mathrm{AlCl}_{3}$ resulting in a virtual absence of dissolved $\left[\mathrm{AlCl}_{4}\right]^{-}[5]$.

Introducing other redox agents and simultaneously forming anions has shown to alter the obtained tellurium homopolycation. Ahmed et al. obtained pure $\mathrm{Te}_{6}\left[\mathrm{WOCl}_{4}\right]_{2}$ by oxidizing elemental tellurium using $\mathrm{WOCl}_{4}$ under otherwise identical conditions compared to the formation of $\mathrm{Te}_{4}\left[\mathrm{AlCl}_{4}\right]_{2}$ [101]. Similarly, Feldmann et al. obtained $\left[\mathrm{Te}_{8}\right]_{2}\left[\mathrm{Ta}_{4} \mathrm{O}_{4} \mathrm{Cl}_{16}\right]$ by reacting elemental tellurium, $\mathrm{TeCl}_{4}, \mathrm{TaOCl}_{3}$, and $\mathrm{TaCl}_{5}$ in the molar ratio of 7:1:2:1 in [BMIm]Cl [103].

A different approach was chosen by Beck et al.: Combining their incomparable expertise on tellurium polycations with the known suitability of ILs as electrolytes resulted in the novel synthesis of tellurium polycations via anodic oxidation of elemental tellurium in ILs. They obtained $\mathrm{Te}_{4}\left[\mathrm{CTf}_{3}\right]_{2}$, $\mathrm{Te}_{6}[\mathrm{Otf}]_{4}$, and $\mathrm{Te}_{8}\left[\mathrm{NTf}_{2}\right]_{2}$ after one to three weeks depending on the chosen IL and voltage [102]. By applying $4 \mathrm{~V}$ in the IL [EMIm][OTf], a red-violet anodic solution was obtained which yielded $\left[\mathrm{Te}_{6}\right][\mathrm{OTf}]_{4}$ upon layering or washing with liquid $\mathrm{SO}_{2}$ at $-60^{\circ} \mathrm{C}$. $\mathrm{Te}_{8}\left[\mathrm{NTf}_{2}\right]_{2}$ was synthesized with a voltage of $6 \mathrm{~V}$ at $50^{\circ} \mathrm{C}$ in $\left[\mathrm{N}(\mathrm{n}-\mathrm{Bu})_{3} \mathrm{Me}\right]\left[\mathrm{NTf}_{2}\right]$. The elevated temperature proved to be necessary due to the high viscosity of the chosen IL, which limited the cell current. Slow diffusion of $\mathrm{CH}_{2} \mathrm{Cl}_{2}$ into the IL initiated the crystallization of the product. Finally, in the synthesis of $\mathrm{Te}_{4}\left[\mathrm{CTf}_{3}\right]_{2}$, $[\mathrm{BMIm}]\left[\mathrm{CTf}_{3}\right]$ acted as conducting salt in liquid $\mathrm{SO}_{2}$ at $-60{ }^{\circ} \mathrm{C}$ and for voltages of $4-6 \mathrm{~V}$. The precipitation was achieved by slow evaporation of $\mathrm{SO}_{2}$.

\subsection{Antimony-Selenium Heteropolycations-Auxilaries, Temperature, and Influence of Halogens}

In recent years, we synthesized several binary or ternary antimony-selenium heteropolycations (Figure 6) in Lewis-acidic ILs [BMIm]X $n \mathrm{AlX}_{3}(X=\mathrm{Cl}, \mathrm{Br} ; n=1.2-5.2)$ [30,34,35,38]. Thereby, we deduced two main decisive reaction parameters for the controlled synthesis of a desired polycation in this system: temperature and the utilization of different auxiliaries. In all reactions, elemental antimony and grey selenium were employed as main starting materials.

If $\mathrm{SeCl}_{4}$ is added to $\mathrm{Sb}$ and Se in $[\mathrm{BMIm}] \mathrm{Cl} \cdot n \mathrm{AlCl}_{3}$, $\left[\mathrm{Sb}_{10} \mathrm{Se}_{10}\right]\left[\mathrm{AlCl}_{4}\right]_{2}$ can be accessed at room temperature [35]. However, if $\mathrm{SeCl}_{4}$ is omitted, either the catena-compound $\left[\mathrm{Sb}_{2} \mathrm{Se}_{2}\right]\left[\mathrm{AlCl}_{4}\right]$ or the cluster compound $\left[\mathrm{Sb}_{13} \mathrm{Se}_{16}\right]\left[\mathrm{AlCl}_{4}\right]_{6} \mathrm{Al}_{2} \mathrm{Cl}_{7}$ form depending on the reaction temperature [30,34]. Thereby, $\left[\mathrm{Sb}_{13} \mathrm{Se}_{16}\right]\left[\mathrm{AlCl}_{4}\right]_{6} \mathrm{Al}_{2} \mathrm{Cl}_{7}$ can be interpreted as intermediate during the decomposition of $\left[\mathrm{Sb}_{2} \mathrm{Se}_{2}\right]\left[\mathrm{AlCl}_{4}\right]$ into $\mathrm{Sb}_{2} \mathrm{Se}_{3}$. However, this thwarts the isolation of pure $\left[\mathrm{Sb}_{13} \mathrm{Se}_{16}\right]\left[\mathrm{AlCl}_{4}\right]_{6} \mathrm{Al}_{2} \mathrm{Cl}_{7}$ due to its narrow temperature range of existence.

The related spiro-heterocubanes $\left.\left.\left[\mathrm{Sb}_{7} \mathrm{Se}_{8} \mathrm{Br}_{2}\right][\mathrm{AlX}]_{4}\right]_{3},\left[\mathrm{Sb}_{13} \mathrm{Se}_{16} \mathrm{Br}_{2}\right][\mathrm{AlX}]_{4}\right]_{5}$, and $\left[\mathrm{Sb}_{7} \mathrm{Se}_{8} \mathrm{Br}_{2}\right]$ $\left[\mathrm{Sb}_{13} \mathrm{Se}_{16} \mathrm{Br}_{2}\right]\left[\mathrm{AlBr}_{4}\right]_{8}$ are obtained from mixtures of [BMIm] Br with $\mathrm{AlCl}_{3}, \mathrm{AlBr}_{3}$, and /or $\mathrm{NbCl}_{5}$ at $160{ }^{\circ} \mathrm{C}$ [38]. If only $\mathrm{AlBr}_{3}$ is present, $\left[\mathrm{Sb}_{7} \mathrm{Se}_{8} \mathrm{Br}_{2}\right]\left[\mathrm{Sb}_{13} \mathrm{Se}_{16} \mathrm{Br}_{2}\right]\left[\mathrm{AlBr}_{4}\right]_{8}$ precipitates exclusively. However, $\left[\mathrm{Sb}_{13} \mathrm{Se}_{16} \mathrm{Br}_{2}\right]\left[\mathrm{AlX}_{4}\right]_{5}$ crystalizes if $\mathrm{AlCl}_{3}$ is employed instead. Finally, by combining $\mathrm{AlBr}_{3}$ and $\mathrm{NbCl}_{5}$, $\left[\mathrm{Sb}_{7} \mathrm{Se}_{8} \mathrm{Br}_{2}\right]\left[\mathrm{AlX}_{4}\right]_{3}$ forms. 


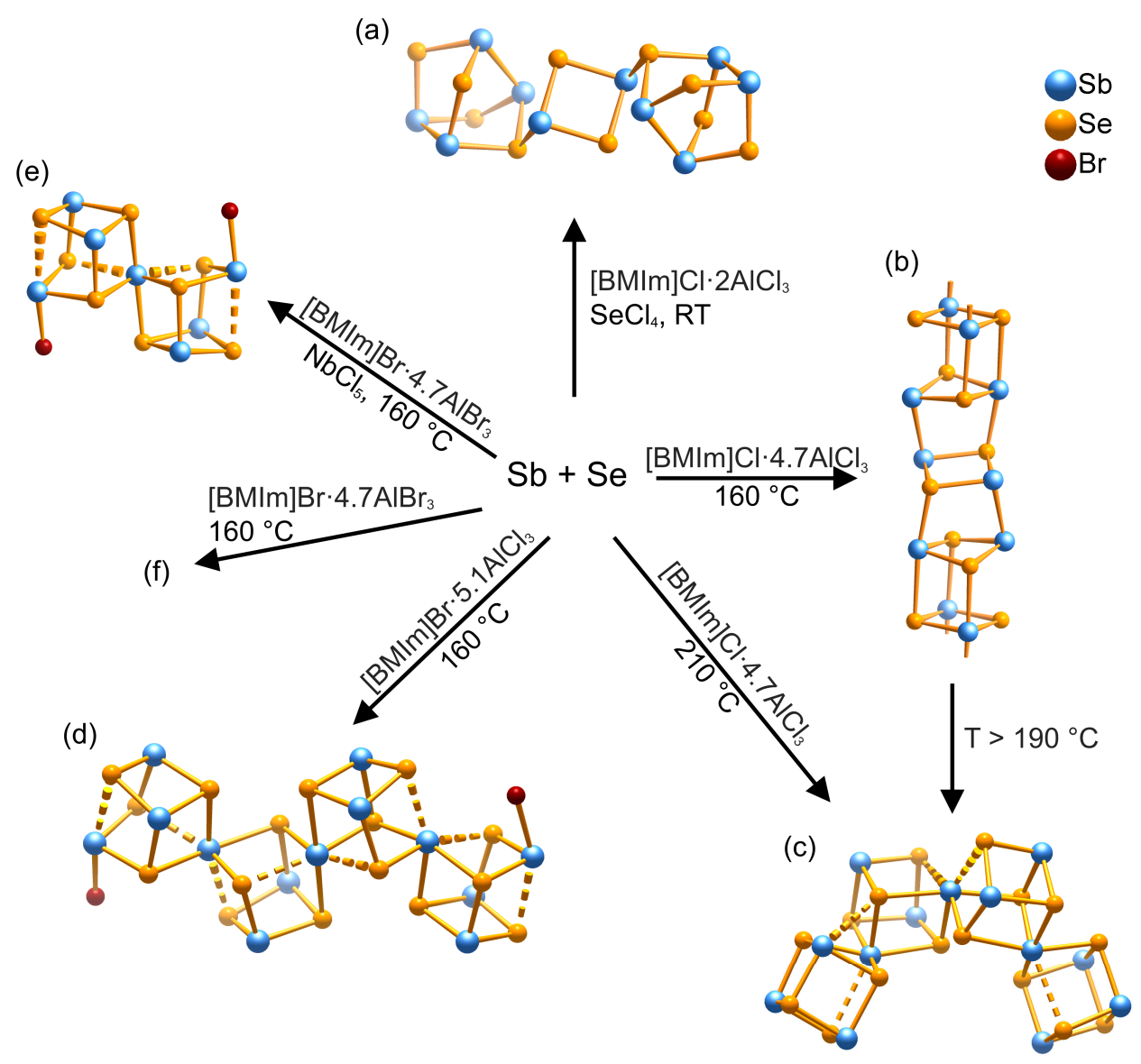

Figure 6. Synopsis of antimony-selenium heteropolycations accessible in ILs and their respective synthetic approach. (a) $\left[\mathrm{Sb}_{10} \mathrm{Se}_{10}\right]^{2+}$ in $\left[\mathrm{Sb}_{10} \mathrm{Se}_{10}\right]\left[\mathrm{AlCl}_{4}\right]_{2}[35] ;(\mathbf{b}){ }_{\infty}^{1}\left[\mathrm{Sb}_{2} \mathrm{Se}_{2}\right]^{+}$in $\left[\mathrm{Sb}_{2} \mathrm{Se}_{2}\right]\left[\mathrm{AlCl}_{4}\right]$ [34]; (c) $\left[\mathrm{Sb}_{13} \mathrm{Se}_{16}\right]^{7+}$ in $\left[\mathrm{Sb}_{13} \mathrm{Se}_{16}\right]\left[\mathrm{AlCl}_{4}\right]_{6} \mathrm{Al}_{2} \mathrm{Cl}_{7}$ [30,34]; (d) $\left[\mathrm{Sb}_{13} \mathrm{Se}_{16} \mathrm{Br}_{2}\right]^{5+}$ in $\left[\mathrm{Sb}_{13} \mathrm{Se}_{16} \mathrm{Br}_{2}\right]\left[\mathrm{AlX}_{4}\right]_{5}$ [38]; (e) $\left[\mathrm{Sb}_{7} \mathrm{Se}_{8} \mathrm{Br}_{2}\right]^{3+}$ in $\left.\left[\mathrm{Sb}_{7} \mathrm{Se}_{8} \mathrm{Br}_{2}\right][\mathrm{AlX}]_{4}\right]_{3}[38]$; and (f) $\left[\mathrm{Sb}_{7} \mathrm{Se}_{8} \mathrm{Br}_{2}\right]^{3+}$ and $\left[\mathrm{Sb}_{13} \mathrm{Se}_{16} \mathrm{Br}_{2}\right]^{5+}$ coexist in $\left[\mathrm{Sb}_{7} \mathrm{Se}_{8} \mathrm{Br}_{2}\right]\left[\mathrm{Sb}_{13} \mathrm{Se}_{16} \mathrm{Br}_{2}\right]\left[\mathrm{AlBr}_{4}\right]_{8}$ [38]. Dashed lines represent longer distances that might be interpreted as secondary bonds [30,38].

\subsection{Bismuth-Tellurium Heteropolycations-Adjustments via Starting Materials}

In a fashion similar to the aforementioned case of antimony and selenium, heteropolycations of bismuth and tellurium (and bromine) can be synthesized in Lewis-acidic ILs. In this system, however, the choice of starting materials seems to have the dominant influence on the obtained polycation.

Starting from elemental bismuth and tellurium, Kanatzidis et al. synthesized $\left[\mathrm{Bi}_{2} \mathrm{Te}_{2} \mathrm{Br}\right]\left[\mathrm{AlCl}_{4}\right]$ and $\left[\left(\mathrm{Bi}_{4} \mathrm{Te}_{4} \mathrm{Br}_{2}\right)\left(\mathrm{Al}_{2} \mathrm{Cl}_{5.46} \mathrm{Br}_{0.54}\right)\right] \mathrm{Cl}_{2}$ in [EMIM] Br$\cdot 4.8 \mathrm{AlCl}_{3}$ at $165{ }^{\circ} \mathrm{C}$. Seemingly by changing the bismuth to tellurium ratio from 1:1 to 1:3, the latter compound was favored [33,45].

In chloride-free [BMIm]Br-4.1 $\mathrm{AlBr}_{3}$, either the cube-shaped polycation $\left[\mathrm{Bi}_{4} \mathrm{Te}_{4}\right]^{4+}$ or the realgar-like $\left[\mathrm{Bi}_{6} \mathrm{Te}_{4} \mathrm{Br}_{2}\right]^{4+}$ forms at $100{ }^{\circ} \mathrm{C}$ depending on the employed starting materials [30]. If bismuth telluride and bismuth tribromide are reacted, $\left[\mathrm{Bi}_{4} \mathrm{Te}_{4}\right]\left[\mathrm{AlBr}_{4}\right]_{4}$ crystallizes as the sole polycation phase. Without addition of bismuth bromide, $\mathrm{Bi}_{2} \mathrm{Te}_{3}$ shows only low solubility in the employed IL and no formation of a solid product has been observed [30]. The reaction of bismuth, tellurium, and bismuth tribromide under the same conditions, however, leads to the crystallization of $\left[\mathrm{Bi}_{6} \mathrm{Te}_{4} \mathrm{Br}_{2}\right]\left[\mathrm{AlBr}_{4}\right]_{4}$.

In addition, $\left[\mathrm{Bi}_{4} \mathrm{Te}_{4}\right]\left[\mathrm{AlCl}_{4}\right]_{4}[105]$, which has initially been synthesized by Beck et al. in a $\mathrm{NaCl} \cdot 11 \mathrm{AlCl}_{3}$ melt at $130{ }^{\circ} \mathrm{C}$, was synthesized by reacting bismuth telluride and bismuth trichloride in $[\mathrm{BMIm}] \mathrm{Cl} \cdot 4.7 \mathrm{AlCl}_{3}$ at $100{ }^{\circ} \mathrm{C}$. Thereby, the yield could be significantly improved compared to the original approach [30]. 


\subsection{Manipulating the Stacking Order of Layered Compounds}

Recently, we proved that the choice of starting materials can even influence the crystallized polytype of a layered compound, namely $\mathrm{Cu}_{2} \mathrm{Bi}_{2} \mathrm{~S}_{3}\left[\mathrm{AlCl}_{4}\right]_{2}$ [32]. In its structures, $\mathrm{Bi}_{2} \mathrm{~S}_{3}$ molecules are connected by copper ions forming cationic layers that are separated by $\left[\mathrm{AlCl}_{4}\right]^{-}$tetrahedra. Upon dissolving $\mathrm{Cu}_{3} \mathrm{Bi}_{2} \mathrm{~S}_{3} \mathrm{Br}_{2}$ [106] in [BMIm] Cl.3.6 $\mathrm{AlCl}_{3}$ or [EMIm] $\mathrm{Cl} \cdot 3.6 \mathrm{AlCl}_{3}$ at 80 to $200{ }^{\circ} \mathrm{C}$, approximately half of the precursor recrystallizes as $\mathrm{Cu}_{2} \mathrm{Bi}_{2} \mathrm{~S}_{3}\left[\mathrm{AlCl}_{4}\right]_{2}$ with a rhombohedral structure. In addition, small amounts of $\mathrm{Bi}_{5}\left[\mathrm{AlCl}_{4}\right]_{3}$ (vide supra) and a hexagonal polytype are found. The compound is also accessible from $\mathrm{CuCl}, \mathrm{Bi}_{2} \mathrm{~S}_{3}$, and $\mathrm{AlCl}_{3}$ at $200{ }^{\circ} \mathrm{C}$ either by solvent-free reaction or by ionothermal synthesis in $[\mathrm{BMIm}] \mathrm{Cl} \cdot 3 \cdot 6 \mathrm{AlCl}_{3}$. Omitting the IL results in a larger portion of $\mathrm{Bi}_{5}\left[\mathrm{AlCl}_{4}\right]_{3}$ while the rhombohedral polytype is again the main (but only microcrystalline) product. In contrast, reacting the binary starting materials in the IL strongly favors the crystallization of the hexagonal polytype. Substitution of $\mathrm{CuCl}$ with $\mathrm{Cu}_{2} \mathrm{~S}$ and the corresponding amount of $\mathrm{Bi}_{2} \mathrm{~S}_{3}$ with $\mathrm{BiCl}_{3}$ results in the crystallization of similar amounts of both polytypes from the IL.

\subsection{Influence of Concentration and Ion Specification}

Lewis-acidic ILs feature a remarkable solubility for metalloids and their halides, which extends to ternary compounds [29,107] with heavy transition metal elements like $\mathrm{Bi}_{16} \mathrm{PdCl}_{22}=$ [Pd@Bi ${ }_{10}$ ] $\mathrm{Bi}_{6} \mathrm{Cl}_{22}$ [108]. The dissolution of $\mathrm{Bi}_{16} \mathrm{PdCl}_{22}$ in the Lewis-acidic IL [BMIm] Br.4.1 $\mathrm{AlBr}_{3}$ yields $\left[\mathrm{Pd} @ \mathrm{Bi}_{10}\right]\left(\mathrm{AlBr}_{4}\right)_{2}\left(\mathrm{Al}_{2} \mathrm{Br}_{7}\right)_{2}$ or $\left[\mathrm{Pd} @ \mathrm{Bi}_{10}\right]\left(\mathrm{AlBr}_{4}\right)_{4}$ depending on temperature and $/$ or $\mathrm{AlBr}_{3}$ to

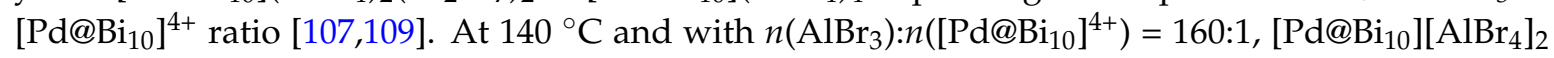
$\left[\mathrm{Al}_{2} \mathrm{Br}_{7}\right]_{2}$ crystallizes, while increasing the reaction temperature or bisecting the ratio yields $\left[\mathrm{Pd} @ \mathrm{Bi}_{10}\right]\left[\mathrm{AlBr}_{4}\right]_{4}$ instead.

The concentration- and/or temperature-driven preference for one of the two compounds can be rationalized with the anion specification in the IL or similar salt melts $[5,100,110]$. At high contents of the aluminum halide (i.e., strongly Lewis-acidic), adducts $\left[\mathrm{Al}_{\mathrm{n}} \mathrm{X}_{3 \mathrm{n}+1}\right]^{-}$prevail. Their lower charge density and symmetry compared to $\left[\mathrm{AlX}_{4}\right]^{-}$, however, strongly disfavors their incorporation into crystal structures. Increasing temperature breaks the adducts and increases the concentration of isolated tetrahedra [100]. A lower amount of dissolved [Pd@Bi $\left.{ }_{10}\right]^{4+}$ polycations leads apparently to the crystallization of tetrahedra pairs owing to the higher excess of pairs.

\section{Conclusions}

The scope of this review is to summarize and deduce decisive reactions parameters for controlled syntheses of polyions of heavy main-group elements in ILs. Without covering all possibilities, we want to demonstrate several (unexpected) pathways to tune reactions in ILs in order to synthesize new compounds. Aside from intuitive parameters such as temperature, concentration of starting materials, or their stoichiometry, syntheses in ILs offer additional ways to control the reaction products such as by the shape and charge-density of the IL cation. For instance, the choice of the starting material can influence the yielded polyion or its polymorph. Auxiliary compounds can be additionally introduced, which for instance subtly adjust the redox potential or influence the dimensionality of polyanions. In addition, general advantages of utilizing ILs are demonstrated such as easier handling of delicate volatile components, provision of dissolved species for further reactions, or substitution of toxic compounds. We would like to encourage readers to explore the abilities of ILs in synthesis because the variety of decisive reaction parameters promises an abundance of possible new compounds. We believe that many discussed reaction principles can be transferred to other classes of compounds, especially in main group-element chemistry. 
Acknowledgments: We are thankful to the DFG (German Science Foundation) for funding within the Priority Program 1708.

Author Contributions: Matthias F. Groh, Alexander Wolff, Matthias A. Grasser, and Michael Ruck wrote the review.

Conflicts of Interest: The authors declare no conflict of interest.

\section{References}

1. Walden, P. Ueber die Molekulargrösse und elektrische Leitfähigkeit einiger geschmolzenen Salze. Izv. Imp. Akad. Nauk 1914, 405-422. (In Germany)

2. Wilkes, J.S. A short history of ionic liquids-From molten salts to neoteric solvents. Green Chem. 2002, 4, 73-80. [CrossRef]

3. Wilkes, J.S.; Wasserscheid, P.; Welton, T. Introduction. In Ionic Liquids in Synthesis; Wasserscheid, P., Welton, T., Eds.; Wiley-VCH Verlag GmbH \& Co. KGaA: Weinheim, Germany, 2007; pp. 1-6.

4. Ahrens, S.; Peritz, A.; Strassner, T. Tunable Aryl Alkyl Ionic Liquids (TAAILs): The next generation of ionic liquids. Angew. Chem. Int. Ed. 2009, 48, 7908-7910. [CrossRef] [PubMed]

5. Estager, J.; Holbrey, J.D.; Swadźba-Kwaśny, M. Halometallate ionic liquids-Revisited. Chem. Soc. Rev. 2014, 43, 847-886. [CrossRef] [PubMed]

6. Mallick, B.; Balke, B.; Felser, C.; Mudring, A.-V. Dysprosium room-temperature ionic liquids with strong luminescence and response to magnetic fields. Angew. Chem. Int. Ed. 2008, 47, 7635-7638. [CrossRef] [PubMed]

7. Visser, A.E.; Swatloski, R.P.; Reichert, W.M.; Griffin, S.T.; Rogers, R.D. Traditional extractants in nontraditional solvents: Groups 1 and 2 extraction by crown ethers in room-temperature ionic liquids. Ind. Eng. Chem. Res. 2000, 39, 3596-3604. [CrossRef]

8. Visser, A.E.; Swatloski, R.P.; Reichert, W.M.; Mayton, R.; Sheff, S.; Wierzbicki, A.; Davis, J.H.; Rogers, R.D. Task-specific ionic liquids incorporating novel cations for the coordination and extraction of $\mathrm{Hg}^{2+}$ and $\mathrm{Cd}^{2+}$ : Synthesis, characterization, and extraction studies. Environ. Sci. Technol. 2002, 36, 2523-2529. [CrossRef] [PubMed]

9. Abai, M.; Atkins, M.P.; Hassan, A.; Holbrey, J.D.; Kuah, Y.; Nockemann, P.; Oliferenko, A.A.; Plechkova, N.V.; Rafeen, S.; Rahman, A.A.; et al. An ionic liquid process for mercury removal from natural gas. Dalton Trans. 2015, 44, 8617-8624. [CrossRef] [PubMed]

10. Zhou, F.; Liang, Y.; Liu, W. Ionic liquid lubricants: Designed chemistry for engineering applications. Chem. Soc. Rev. 2009, 38, 2590-2599. [CrossRef] [PubMed]

11. Endres, F.; Bukowski, M.; Hempelmann, R.; Natter, H. Electrodeposition of nanocrystalline metals and alloys from ionic liquids. Angew. Chem. Int. Ed. 2003, 42, 3428-3430. [CrossRef] [PubMed]

12. Papageorgiou, N.; Athanassov, Y.; Armand, M.; Bonhôte, P.; Pettersson, H.; Azam, A.; Grätzel, M. The performance and stability of ambient temperature molten salts for solar cell applications. J. Electrochem. Soc. 1996, 143, 3099-3108. [CrossRef]

13. Pringle, J.M.; Armel, V. The influence of ionic liquid and plastic crystal electrolytes on the photovoltaic characteristics of dye-sensitised solar cells. Int. Rev. Phys. Chem. 2011, 30, 371-407. [CrossRef]

14. Högberg, D.; Soberats, B.; Uchida, S.; Yoshio, M.; Kloo, L.; Segawa, H.; Kato, T. Nanostructured two-component liquid-crystalline electrolytes for high-temperature dye-sensitized solar cells. Chem. Mater. 2014, 26, 6496-6502. [CrossRef]

15. Seddon, K.R. Ionic liquids for clean technology. J. Chem. Technol. Biotechnol. 1997, 68, 351-356. [CrossRef]

16. Giernoth, R. Task-specific ionic liquids. Angew. Chem. Int. Ed. 2010, 49, 2834-2839. [CrossRef] [PubMed]

17. Duchet, L.; Legeay, J.C.; Carrié, D.; Paquin, L.; Vanden Eynde, J.J.; Bazureau, J.P. Synthesis of 3,5-disubstituted 1,2,4-oxadiazoles using ionic liquid-phase organic synthesis (IoLiPOS) methodology. Tetrahedron 2010, 66, 986-994. [CrossRef]

18. Zhang, Y.; Zuo, C.; Li, C.; Guo, X.; Zhang, S. Carbonyl ruthenium catalysts for the low-temperature water-gas shift reaction with ionic liquids as support structure controllers. Green Chem. 2016. [CrossRef]

19. Kubisa, P. Ionic liquids as solvents for polymerization processes-Progress and challenges. Prog. Polym. Sci. 2009, 34, 1333-1347. [CrossRef] 
20. Reichert, W.M.; Holbrey, J.D.; Vigour, K.B.; Morgan, T.D.; Broker, G.A.; Rogers, R.D. Approaches to crystallization from ionic liquids: Complex solvents-complex results, or, a strategy for controlled formation of new supramolecular architectures? Chem. Commun. 2006, 4767-4779. [CrossRef]

21. Tang, S.; Babai, A.; Mudring, A.-V. Europium-based ionic liquids as luminescent soft materials. Angew. Chem. Int. Ed. 2008, 47, 7631-7634. [CrossRef] [PubMed]

22. Getsis, A.; Tang, S.; Mudring, A.-V. A luminescent ionic liquid crystal: $\left[\mathrm{C}_{12} \mathrm{mim}\right]_{4}\left[\mathrm{EuBr}_{6}\right] \mathrm{Br} . \quad$ Eur. J. Inorg. Chem. 2010, 2010, 2172-2177. [CrossRef]

23. Ahmed, E.; Breternitz, J.; Groh, M.F.; Ruck, M. Ionic liquids as crystallisation media for inorganic materials. CrystEngComm 2012, 14, 4874-4885. [CrossRef]

24. Chesman, A.S.R.; Yang, M.; Spiccia, N.D.; Deacon, G.B.; Batten, S.R.; Mudring, A.-V. Lanthanoid-based ionic liquids incorporating the dicyanonitrosomethanide anion. Chem. Eur. J. 2012, 18, 9580-9589. [CrossRef] [PubMed]

25. Cavallo, G.; Terraneo, G.; Monfredini, A.; Saccone, M.; Priimagi, A.; Pilati, T.; Resnati, G.; Metrangolo, P.; Bruce, D.W. Superfluorinated ionic liquid crystals based on supramolecular, halogen-bonded anions. Angew. Chem. Int. Ed. 2016, 55, 6300-6304. [CrossRef] [PubMed]

26. Groh, M.F.; Müller, U.; Ahmed, E.; Rothenberger, A.; Ruck, M. Substitution of conventional high-temperature syntheses of inorganic compounds by near-room-temperature syntheses in ionic liquids. Z. Naturforsch. 2013, 68b, 1108-1122. [CrossRef]

27. Ahmed, E.; Ruck, M. Homo and heteroatomic polycations of groups 15 and 16. Recent advances in synthesis and isolation using room temperature ionic liquids. Coord. Chem. Rev. 2011, 255, 2892-2903. [CrossRef]

28. Freudenmann, D.; Wolf, S.; Wolff, M.; Feldmann, C. Ionic liquids: New perspectives for inorganic synthesis? Angew. Chem. Int. Ed. 2011, 50, 11050-11060. [CrossRef] [PubMed]

29. Groh, M.F.; Isaeva, A.; Ruck, M. $\left[\mathrm{Ru}_{2} \mathrm{Bi}_{14} \mathrm{Br}_{4}\right]\left(\mathrm{AlCl}_{4}\right)_{4}$ by mobilization and reorganization of complex clusters in ionic liquids. Chem. Eur. J. 2012, 18, 10886-10891. [CrossRef] [PubMed]

30. Groh, M.F.; Isaeva, A.; Müller, U.; Gebauer, P.; Knies, M.; Ruck, M. Controlled synthesis of pnicogen-chalcogen polycations in ionic liquids. Eur. J. Inorg. Chem. 2016, 2016, 880-889. [CrossRef]

31. Ahmed, E.; Beck, J.; Daniels, J.; Doert, T.; Eck, S.J.; Heerwig, A.; Isaeva, A.; Lidin, S.; Ruck, M.; Schnelle, W.; et al. A Semiconductor or a One-Dimensional Metal and Superconductor through Tellurium $\pi$ Stacking. Angew. Chem. Int. Ed. 2012, 51, 8106-8109. [CrossRef] [PubMed]

32. Groh, M.F.; Knies, M.; Isaeva, A.; Ruck, M. Bi $\mathrm{S}_{3}$ bipyramids in layered sulfides $\mathrm{M}_{2} \mathrm{Bi}_{2} \mathrm{~S}_{3}\left(\mathrm{AlCl}_{4}\right)_{2}$ $(M=\mathrm{Ag}, \mathrm{Cu})$. Z. Anorg. Allg. Chem. 2015, 641, 279-284. [CrossRef]

33. Biswas, K.; Zhang, Q.; Chung, I.; Song, J.-H.; Androulakis, J.; Freeman, A.J.; Kanatzidis, M.G. Synthesis in ionic liquids: $\left[\mathrm{Bi}_{2} \mathrm{Te}_{2} \mathrm{Br}\right]\left(\mathrm{AlCl}_{4}\right)$, a direct gap semiconductor with a cationic framework. J. Am. Chem. Soc. 2010, 132, 14760-14762. [CrossRef] [PubMed]

34. Groh, M.F.; Breternitz, J.; Ahmed, E.; Isaeva, A.; Efimova, A.; Schmidt, P.; Ruck, M. Ionothermal synthesis, structure, and bonding of the catena-heteropolycation ${ }_{\infty}^{1}\left[\mathrm{Sb}_{2} \mathrm{Se}_{2}\right]^{+}$. Z. Anorg. Allg. Chem. 2015, 641, 388-393. [CrossRef]

35. Ahmed, E.; Isaeva, A.; Fiedler, A.; Haft, M.; Ruck, M. $\left[\mathrm{Sb}_{10} \mathrm{Se}_{10}\right]^{2+}$, a heteronuclear polycyclic polycation from a room-temperature ionic liquid. Chem. Eur. J. 2011, 17, 6847-6852. [CrossRef] [PubMed]

36. Zhang, Q.; Chung, I.; Jang, J.I.; Ketterson, J.B.; Kanatzidis, M.G. Chalcogenide chemistry in ionic liquids: Nonlinear optical wave-mixing properties of the double-cubane compound $\left[\mathrm{Sb}_{7} \mathrm{~S}_{8} \mathrm{Br}_{2}\right]\left(\mathrm{AlCl}_{4}\right)_{3}$. J. Am. Chem. Soc. 2009, 131, 9896-9897. [CrossRef] [PubMed]

37. Freudenmann, D.; Feldmann, C. $\left[\mathrm{Bi}_{3} \mathrm{GaS}_{5}\right]_{2}\left[\mathrm{Ga}_{3} \mathrm{Cl}_{10}\right]_{2}\left[\mathrm{GaCl}_{4}\right]_{2} \cdot \mathrm{S}_{8}$ containing heterocubane-type $\left[\mathrm{Bi}_{3} \mathrm{GaS}_{5}\right]^{2+}$, star-shaped $\left[\mathrm{Ga}_{3} \mathrm{Cl}_{10}\right]^{-}$, monomeric $\left[\mathrm{GaCl}_{4}\right]^{-}$and crown-like $\mathrm{S}_{8}$. Dalton Trans. 2010, 40, 452-456. [CrossRef] [PubMed]

38. Ahmed, E.; Breternitz, J.; Groh, M.F.; Isaeva, A.; Ruck, M. [ $\left[\mathrm{Sb}_{7} \mathrm{Se}_{8} \mathrm{Br}_{2}\right]^{3+}$ and $\left[\mathrm{Sb}_{13} \mathrm{Se}_{16} \mathrm{Br}_{2}\right]^{5+}$-Double and quadruple spiro cubanes from ionic liquids. Eur. J. Inorg. Chem. 2014, 2014, 3037-3042. [CrossRef]

39. Feldmann, K.-O.; Wiegand, T.; Ren, J.; Eckert, H.; Breternitz, J.; Groh, M.F.; Müller, U.; Ruck, M.; Maryasin, B.; Ochsenfeld, C.; et al. $\left[\mathrm{P}_{3} \mathrm{Se}_{4}\right]^{+}$: A binary phosphorus-selenium cation. Chem. Eur. J. 2015, 21, 9697-9712. [CrossRef] [PubMed]

40. Guloy, A.M.; Ramlau, R.; Tang, Z.; Schnelle, W.; Baitinger, M.; Grin, Y. A guest-free germanium clathrate. Nature 2006, 443, 320-323. [CrossRef] [PubMed]

41. Taubert, A.; Li, Z. Inorganic materials from ionic liquids. Dalton Trans. 2007, 723-727. [CrossRef] [PubMed] 
42. Vollmer, C.; Janiak, C. Naked metal nanoparticles from metal carbonyls in ionic liquids: Easy synthesis and stabilization. Coord. Chem. Rev. 2011, 255, 2039-2057. [CrossRef]

43. Wolff, M.; Meyer, J.; Feldmann, C. $\left[\mathrm{C}_{4} \mathrm{MPyr}_{2}\left[\mathrm{Br}_{20}\right]\right.$ : Ionic-liquid-based synthesis of a three-dimensional polybromide network. Angew. Chem. Int. Ed. 2011, 50, 4970-4973. [CrossRef] [PubMed]

44. Du, K.-Z.; Feng, M.-L.; Li, J.-R.; Huang, X.-Y. Ionothermal synthesis and characterization of two cluster chalcohalides: $\left[\mathrm{Cr}_{7} \mathrm{~S}_{8} \mathrm{Cl}_{2}\left(\mathrm{NH}_{3}\right)_{14.5}\left(\mathrm{H}_{2} \mathrm{O}\right)_{1.5}\right] \mathrm{Cl}_{3} \cdot \mathrm{H}_{2} \mathrm{O}$ and $[\mathrm{Emim}]_{2}\left[\mathrm{Sn}_{2} \mathrm{As}_{2} \mathrm{~S}_{4}\left(\mathrm{~S}_{2}\right)_{2} \mathrm{Br}_{2.43} \mathrm{Cl}_{1.56}\right]$. CrystEngComm 2013, 15, 5594-5597. [CrossRef]

45. Biswas, K.; Chung, I.; Song, J.-H.; Malliakas, C.D.; Freeman, A.J.; Kanatzidis, M.G. Semiconducting $\left[\left(\mathrm{Bi}_{4} \mathrm{Te}_{4} \mathrm{Br}_{2}\right)\left(\mathrm{Al}_{2} \mathrm{Cl}_{6-x} \mathrm{Br}_{\mathrm{x}}\right)\right] \mathrm{Cl}_{2}$ and $\left[\mathrm{Bi}_{2} \mathrm{Se}_{2} \mathrm{Br}\right]\left(\mathrm{AlCl}_{4}\right)$ : Cationic chalcogenide frameworks from lewis acidic ionic liquids. Inorg. Chem. 2013, 52, 5657-5659. [CrossRef] [PubMed]

46. Schütte, K.; Meyer, H.; Gemel, C.; Barthel, J.; Fischer, R.A.; Janiak, C. Synthesis of Cu, Zn and Cu/Zn brass alloy nanoparticles from metal amidinate precursors in ionic liquids or propylene carbonate with relevance to methanol synthesis. Nanoscale 2014, 6, 3116-3126. [CrossRef] [PubMed]

47. Tyrrell, S.; Swadźba-Kwaśny, M.; Nockemann, P. Ionothermal, microwave-assisted synthesis of indium(III) selenide. J. Mater. Chem. A 2014, 2, 2616-2622. [CrossRef]

48. Gebresilassie Eshetu, G.; Armand, M.; Scrosati, B.; Passerini, S. Energy storage materials synthesized from ionic liquids. Angew. Chem. Int. Ed. 2014, 53, 13342-13359. [CrossRef] [PubMed]

49. Alammar, T.; Chow, Y.-K.; Mudring, A.-V. Energy efficient microwave synthesis of mesoporous $\mathrm{Ce}_{0.5} \mathrm{M}_{0.5} \mathrm{O}_{2}$ (Ti, Zr, Hf) nanoparticles for low temperature $\mathrm{CO}$ oxidation in an ionic liquid-A comparative study. New J. Chem. 2015, 39, 1339-1347. [CrossRef]

50. Bresien, J.; Ellinger, S.; Harloff, J.; Schulz, A.; Sievert, K.; Stoffers, A.; Täschler, C.; Villinger, A.; Zur Täschler, C. Tetracyanido(difluorido)phosphates $\mathrm{M}^{+}\left[\mathrm{PF}_{2}(\mathrm{CN})_{4}\right]^{-}$. Angew. Chem. Int. Ed. 2015, 54, 4474-4477. [CrossRef] [PubMed]

51. Santner, S.; Heine, J.; Dehnen, S. Synthesis of crystalline chalcogenides in ionic liquids. Angew. Chem. Int. Ed. 2016, 55, 876-893. [CrossRef] [PubMed]

52. Taubert, A. Heavy Elements in Ionic Liquids. In Ionic Liquids; Kirchner, B., Ed.; Topics in Current Chemistry; Springer: Berlin \& Heidelberg, Germany, 2009; pp. 127-159.

53. Janiak, C. Ionic liquids for the synthesis and stabilization of metal nanoparticles. Z. Naturforsch. 2013, 68b, 1059-1089. [CrossRef]

54. Morris, R.E. Ionothermal Synthesis of Zeolites and Other Porous Materials. In Zeolites and Catalysis; Čejka, J., Corma, A., Zones, S., Eds.; Wiley-VCH Verlag GmbH \& Co. KGaA: Weinheim, Germany, 2010; pp. 87-105.

55. Mudring, A.-V.; Tang, S. Ionic liquids for lanthanide and actinide chemistry. Eur. J. Inorg. Chem. 2010, 2010, 2569-2581. [CrossRef]

56. Prechtl, M.H.G.; Campbell, P.S. Metal oxide and bimetallic nanoparticles in ionic liquids: Synthesis and application in multiphase catalysis. Nanotechnol. Rev. 2013, 2, 577-595. [CrossRef]

57. Zhu, Y.-J.; Chen, F. Microwave-assisted preparation of inorganic nanostructures in liquid phase. Chem. Rev. 2014, 114, 6462-6555. [CrossRef] [PubMed]

58. Ma, Z.; Yu, J.; Dai, S. Preparation of inorganic materials using ionic liquids. Adv. Mater. 2010, 22, $261-285$. [CrossRef] [PubMed]

59. Ahmed, E.; Ruck, M. Chemistry of polynuclear transition-metal complexes in ionic liquids. Dalton Trans. 2011, 40, 9347-9357. [CrossRef] [PubMed]

60. Groh, M.F.; Paasch, S.; Weiz, A.; Ruck, M.; Brunner, E. Unexpected reactivity of red phosphorus in ionic liquids. Eur. J. Inorg. Chem. 2015, 2015, 3991-3994. [CrossRef]

61. Xu, R.; Zhang, W.; Guan, J.; Xu, Y.; Wang, L.; Ma, H.; Tian, Z.; Han, X.; Lin, L.; Bao, X. New insights into the role of amines in the synthesis of molecular sieves in ionic liquids. Chem. Eur. J. 2009, 15, 5348-5354. [CrossRef] [PubMed]

62. Xu, R.; Shi, X.; Zhang, W.; Xu, Y.; Tian, Z.; Lu, X.; Han, X.; Bao, X. Cooperative structure-directing effect in the synthesis of aluminophosphate molecular sieves in ionic liquids. Phys. Chem. Chem. Phys. 2010, 12, 2443-2449. [CrossRef] [PubMed]

63. Ahmed, E.; Ruck, M. Ionothermal synthesis of polyoxometalates. Angew. Chem. Int. Ed. 2012, 51, 308-309. [CrossRef] [PubMed]

64. Lei, Z.; Dai, C.; Chen, B. Gas Solubility in Ionic Liquids. Chem. Rev. 2014, 114, 1289-1326. [CrossRef] [PubMed] 
65. Jacquemin, J.; Costa Gomes, M.F.; Husson, P.; Majer, V. Solubility of carbon dioxide, ethane, methane, oxygen, nitrogen, hydrogen, argon, and carbon monoxide in 1-butyl-3-methylimidazolium tetrafluoroborate between temperatures $283 \mathrm{~K}$ and $343 \mathrm{~K}$ and at pressures close to atmospheric. J. Chem. Thermodyn. 2006, 38, 490-502. [CrossRef]

66. Torralba-Calleja, E.; Skinner, J.; Gutierrez-Tauste, D. $\mathrm{CO}_{2}$ Capture in ionic liquids: A review of solubilities and experimental methods. J. Chem. 2013, 2013, e473584. [CrossRef]

67. Anthony, J.L.; Anderson, J.L.; Maginn, E.J.; Brennecke, J.F. Anion effects on gas solubility in ionic liquids. J. Phys. Chem. B 2005, 109, 6366-6374. [CrossRef] [PubMed]

68. Tempel, D.J.; Henderson, P.B.; Brzozowski, J.R.; Pearlstein, R.M.; Cheng, H. High gas storage capacities for ionic liquids through chemical complexation. J. Am. Chem. Soc. 2008, 130, 400-401. [CrossRef] [PubMed]

69. Wolff, M.; Okrut, A.; Feldmann, C. [(Ph) $\left.)_{3} \mathrm{PBr}\right][\mathrm{Br} 7],\left[(\mathrm{Bz})(\mathrm{Ph})_{3} \mathrm{P}\right]_{2}\left[\mathrm{Br}_{8}\right],\left[(\mathrm{n}-\mathrm{Bu})_{3} \mathrm{MeN}\right]_{2}\left[\mathrm{Br}_{20}\right],\left[\mathrm{C}_{4} \mathrm{MPyr}_{2}\left[\mathrm{Br}_{20}\right]\right.$, and $\left[(\mathrm{Ph})_{3} \mathrm{PCl}\right]_{2}\left[\mathrm{Cl}_{2} \mathrm{I}_{14}\right]$ : Extending the horizon of polyhalides via synthesis in ionic liquids. Inorg. Chem. 2011, 50, 11683-11694. [CrossRef] [PubMed]

70. Haller, H.; Hog, M.; Scholz, F.; Scherer, H.; Krossing, I.; Riedel, S. [HMIM][Br, ]: A Room-temperature ionic liquid based on a polybromide anion. Z. Naturforsch. 2014, 68b, 1103-1107. [CrossRef]

71. Easton, M.E.; Ward, A.J.; Hudson, T.; Turner, P.; Masters, A.F.; Maschmeyer, T. The formation of high-order polybromides in a room-temperature ionic liquid: From monoanions $\left(\left[\mathrm{Br}_{5}\right]^{-}\right.$to $\left.\left[\mathrm{Br}_{11}\right]^{-}\right)$to the Isolation of $\left[\mathrm{PC}_{16} \mathrm{H}_{36}\right]_{2}\left[\mathrm{Br}_{24}\right]$ as determined by van der waals bonding radii. Chem. Eur. J. 2015, 21, 2961-2965. [CrossRef] [PubMed]

72. Easton, M.E.; Ward, A.J.; Chan, B.; Radom, L.; Masters, A.F.; Maschmeyer, T. Factors influencing the formation of polybromide monoanions in solutions of ionic liquid bromide salts. Phys. Chem. Chem. Phys. 2016, 18, 7251-7260. [CrossRef] [PubMed]

73. Svensson, P.H.; Kloo, L. Synthesis, structure, and bonding in polyiodide and metal iodide-iodine Systems. Chem. Rev. 2003, 103, 1649-1684. [CrossRef] [PubMed]

74. Cunningham, C.W.; Burns, G.R.; McKee, V. A new polyhalogen network for bromine- $\mathrm{Br}_{10}{ }^{2-}$. Inorg. Chim. Acta 1990, 167, 135-137. [CrossRef]

75. Aragoni, M.C.; Arca, M.; Devillanova, F.A.; Isaia, F.; Lippolis, V.; Mancini, A.; Pala, L.; Slawin, A.M.Z.; Woollins, J.D. First example of an infinite polybromide 2D-network. Chem. Commun. 2003, 2226-2227. [CrossRef]

76. Haller, H.; Riedel, S. Recent discoveries of polyhalogen anions-From bromine to fluorine. Z. Anorg. Allg. Chem. 2014, 640, 1281-1291. [CrossRef]

77. CRC Handbook of Chemistry and Physics, 94th ed.; Haynes, W.M., Ed.; CRC Press: Boca Raton, FL, USA, 2013.

78. Sowmiah, S.; Srinivasadesikan, V.; Tseng, M.-C.; Chu, Y.-H. On the chemical stabilities of ionic liquids. Molecules 2009, 14, 3780-3813. [CrossRef] [PubMed]

79. Brown, R.J.C.; Dyson, P.J.; Ellis, D.J.; Welton, T. 1-Butyl-3-methylimidazolium cobalt tetracarbonyl [bmim $]\left[\mathrm{Co}(\mathrm{CO})_{4}\right]$ : A catalytically active organometallic ionic liquid. Chem. Commun. 2001, 1862-1863. [CrossRef]

80. Wolf, S.; Feldmann, C. [(Te $\left.)_{3}\left\{\mathrm{Mn}(\mathrm{CO})_{3}\right\}_{2}\left\{\mathrm{Mn}(\mathrm{CO})_{4}\right\}_{3}\right]^{-}$-A Novel Tellurium-Manganese Carbonyl with Ufosane-like Structure. Z. Anorg. Allg. Chem. 2012, 638, 1787-1791. [CrossRef]

81. Wolf, S.; Reiter, K.; Weigend, F.; Klopper, W.; Feldmann, C. [( $\left.\left.\mathrm{Pb}_{6} \mathrm{I}_{8}\right)\left\{\mathrm{Mn}(\mathrm{CO})_{5}\right\}_{6}\right]^{2-}$ : An Octahedral $\left(\mathrm{M}_{6} \mathrm{X}_{8}\right)$-like Cluster with Inverted Bonding. Inorg. Chem. 2015, 54, 3989-3994. [CrossRef] [PubMed]

82. Wolf, S.; Winter, F.; Pöttgen, R.; Middendorf, N.; Klopper, W.; Feldmann, C. [XIm] $\left[\mathrm{FeI}(\mathrm{CO})_{3}\left(\mathrm{SnI}_{3}\right)_{2}\right]$ (XIm: EMIm, EHIm, PMIm) containing a barbell-shaped FeSn 2 -carbonyl complex. Dalton Trans. 2012, 41, 10605-10611. [CrossRef] [PubMed]

83. Wolf, S.; Winter, F.; Pöttgen, R.; Middendorf, N.; Klopper, W.; Feldmann, C. $\left[\left\{\mathrm{Fe}(\mathrm{CO})_{3}\right\}_{4}\{\mathrm{SnI}\}_{6} \mathrm{I}_{4}\right]^{2-}$ : The first bimetallic adamantane-like cluster. Chem. Eur. J. 2012, 18, 13600-13604. [CrossRef] [PubMed]

84. Cooper, E.R.; Andrews, C.D.; Wheatley, P.S.; Webb, P.B.; Wormald, P.; Morris, R.E. Ionic liquids and eutectic mixtures as solvent and template in synthesis of zeolite analogues. Nature 2004, 430, 1012-1016. [CrossRef] [PubMed]

85. Parnham, E.R.; Drylie, E.A.; Wheatley, P.S.; Slawin, A.M.Z.; Morris, R.E. Ionothermal materials synthesis using unstable deep-eutectic solvents as template-delivery agents. Angew. Chem. Int. Ed. 2006, 45, 4962-4966. [CrossRef] [PubMed] 
86. Morris, R.E. Ionothermal synthesis-Ionic liquids as functional solvents in the preparation of crystalline materials. Chem. Commun. 2009, 2990-2998. [CrossRef] [PubMed]

87. Wragg, D.S.; Slawin, A.M.Z.; Morris, R.E. The role of added water in the ionothermal synthesis of microporous aluminium phosphates. Solid State Sci. 2009, 11, 411-416. [CrossRef]

88. Pei, R.; Wei, Y.; Li, K.; Wen, G.; Xu, R.; Xu, Y.; Wang, L.; Ma, H.; Wang, B.; Tian, Z.; et al. Mixed template effect adjusted by amine concentration in ionothermal synthesis of molecular sieves. Dalton Trans. 2010, 39, 1441-1443. [CrossRef] [PubMed]

89. Wang, L.; Xu, Y.; Wei, Y.; Duan, J.; Chen, A.; Wang, B.; Ma, H.; Tian, Z.; Lin, L. Structure-Directing Role of Amines in the Ionothermal Synthesis. J. Am. Chem. Soc. 2006, 128, 7432-7433. [CrossRef] [PubMed]

90. Li, J.-R.; Xie, Z.-L.; He, X.-W.; Li, L.-H.; Huang, X.-Y. Crystalline Open-Framework Selenidostannates Synthesized in Ionic Liquids. Angew. Chem. Int. Ed. 2011, 50, 11395-11399. [CrossRef] [PubMed]

91. Lin, Y.; Massa, W.; Dehnen, S. "Zeoball" $\left[\mathrm{Sn}_{36} \mathrm{Ge}_{24} \mathrm{Se}_{132}\right]^{24-}$ : A molecular anion with zeolite-related composition and spherical shape. J. Am. Chem. Soc. 2012, 134, 4497-4500. [CrossRef] [PubMed]

92. Lin, Y.; Massa, W.; Dehnen, S. Controlling the assembly of chalcogenide anions in ionic liquids: From binary Ge/Se through ternary Ge/Sn/Se to binary Sn/Se frameworks. Chem. Eur. J. 2012, 18, 13427-13434. [CrossRef] [PubMed]

93. Lin, Y.; Xie, D.; Massa, W.; Mayrhofer, L.; Lippert, S.; Ewers, B.; Chernikov, A.; Koch, M.; Dehnen, S. Changes in the structural dimensionality of selenidostannates in ionic liquids: Formation, structures, stability, and photoconductivity. Chem. Eur. J. 2013, 19, 8806-8813. [CrossRef] [PubMed]

94. Li, J.-R.; Xiong, W.-W.; Xie, Z.-L.; Du, C.-F.; Zou, G.-D.; Huang, X.-Y. From selenidostannates to silver-selenidostannate: Structural variation of chalcogenidometallates synthesized in ionic liquids. Chem. Commun. 2012, 49, 181-183. [CrossRef] [PubMed]

95. Santner, S.; Dehnen, S. $\left[\mathrm{M}_{4} \mathrm{Sn}_{4} \mathrm{Se}_{17}\right]^{10-}$ Cluster Anions $(\mathrm{M}=\mathrm{Mn}, \mathrm{Zn}, \mathrm{Cd})$ in a Cs ${ }^{+}$Environment and as ternary precursors for ionothermal treatment. Inorg. Chem. 2015, 54, 1188-1190. [CrossRef] [PubMed]

96. Du, C.-F.; Li, J.-R.; Feng, M.-L.; Zou, G.-D.; Shen, N.-N.; Huang, X.-Y. Varied forms of lamellar $\left[\mathrm{Sn}_{3} \mathrm{Se}_{7}\right]_{n}{ }^{2 n-}$ anion: The competitive and synergistic structure-directing effects of metal-amine complex and imidazolium cations. Dalton Trans. 2015, 44, 7364-7372. [CrossRef] [PubMed]

97. Du, C.-F.; Shen, N.-N.; Li, J.-R.; Hao, M.-T.; Wang, Z.; Cheng, C.-C.; Huang, X.-Y. Two novel selenidostannates from mixed structure-directing systems: The large ten-membered ring of [Sn3Se4] semicubes and the 3D [Sn $\left.\mathrm{Se}_{9}\right]_{\mathrm{n}}{ }^{2 \mathrm{n}-}$ with multi-channels. Dalton Trans. 2016, 45, 9523-9528. [CrossRef] [PubMed]

98. Du, C.-F.; Shen, N.-N.; Li, J.-R.; Hao, M.-T.; Wang, Z.; Huang, X.-Y. Synthesizing 2D and 3D selenidostannates in ionic liquids: The synergistic structure-directing effects of ionic liquids and metal-amine complexes. Chem. Asian J. 2016, 11, 1555-1564. [CrossRef] [PubMed]

99. Ahmed, E.; Köhler, D.; Ruck, M. Room-temperature synthesis of bismuth clusters in ionic liquids and crystal growth of $\mathrm{Bi}_{5}\left(\mathrm{AlCl}_{4}\right)_{3}$. Z. Anorg. Allg. Chem. 2009, 635, 297-300. [CrossRef]

100. Boxall, L.G.; Jones, H.L.; Osteryoung, R.A. Solvent equilibria of $\mathrm{AlCl}_{3}-\mathrm{NaCl}$ melts. J. Electrochem. Soc. 1973, 120, 223-231. [CrossRef]

101. Ahmed, E.; Ahrens, E.; Heise, M.; Ruck, M. A facile route for the synthesis of polycationic tellurium cluster compounds: Synthesis in ionic liquid media and characterization by single-crystal X-ray crystallography and magnetic susceptibility. Z. Anorg. Allg. Chem. 2010, 636, 2602-2606. [CrossRef]

102. Schulz, C.; Daniels, J.; Bredow, T.; Beck, J. The electrochemical synthesis of polycationic clusters. Angew. Chem. Int. Ed. 2016, 55, 1173-1177. [CrossRef] [PubMed]

103. Freudenmann, D.; Feldmann, C. $\left[\mathrm{Te}_{8}\right]_{2}\left[\mathrm{Ta}_{4} \mathrm{O}_{4} \mathrm{Cl}_{16}\right]$ : A Two-dimensional tellurium polycation obtained via ionic liquid-based synthesis. Z. Anorg. Allg. Chem. 2011, 637, 1481-1485. [CrossRef]

104. Åkerstedt, J.; Gorlov, M.; Kloo, L. Room-temperature synthesis of the $\mathrm{Bi}_{5}\left[\mathrm{GaCl}_{4}\right]_{3}$ salt from three different classes of ionic liquids. J. Cluster Sci. 2012, 24, 157-164. [CrossRef]

105. Beck, J.; Dolg, M.; Schlüter, S. $\mathrm{Bi}_{4} \mathrm{Te}_{4}{ }^{4+}-\mathrm{A}$ cube-shaped, polycationic main group element cluster. Angew. Chem. Int. Ed. 2001, 40, 2287-2290. [CrossRef]

106. Heerwig, A.; Ruck, M. The Low-valent bismuth sulfide bromide $\mathrm{Cu}_{3} \mathrm{Bi}_{2} \mathrm{~S}_{3} \mathrm{Br}_{2}$. Z. Anorg. Allg. Chem. 2011, 637, 1814-1817. [CrossRef]

107. Groh, M.F.; Ruck, M. Mobilization and modification of intermetalloid clusters in ionic liquids. Z. Anorg. Allg. Chem. 2014, 640, 2391. 
108. Dubenskyy, V.; Ruck, M. Das Subchlorid $\mathrm{Bi}_{16} \mathrm{PdCl}_{22}$ : $\mathrm{Pd@Bi} 10{ }^{4+}$-polykationen in einem raumnetzwerk aus chlorobismutat(III)-anionen. Z. Anorg. Allg. Chem. 2004, 630, 2458-2462. [CrossRef]

109. Groh, M.F.; Wolff, A.; Wahl, B.; Rasche, B.; Gebauer, P.; Ruck, M. Pentagonal Bismuth antiprisms with endohedral palladium or platinum atoms by low-temperature syntheses. Chem. Eur. J. 2016, submitted.

110. Blander, M.; Bierwagen, E.; Calkins, K.G.; Curtiss, L.A.; Price, D.L.; Saboungi, M.-L. Structure of acidic haloaluminate melts: Neutron diffraction and quantum chemical calculations. J. Chem. Phys. 1992, 97, 2733-2741. [CrossRef]

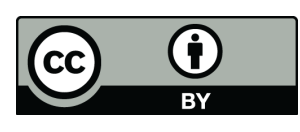

(c) 2016 by the authors; licensee MDPI, Basel, Switzerland. This article is an open access article distributed under the terms and conditions of the Creative Commons Attribution (CC-BY) license (http://creativecommons.org/licenses/by/4.0/). 